\title{
J(৫)
}

Received: 13.06 .2019

Accepted: 20.06.2019

Published: 24.06 .2019

JOTS, 3/2, 2019: 372-408

\section{Orhun Yazıtlarındaki Durum Eklerinin Sentaktik İşlevleri Üzerine}

\section{On the Syntactic Functions of the Case Suffixes in the Orkhon Inscriptions}

\author{
Hulusi PoLAT \\ Inönü University (Malatya/Turkey) \\ E-mail: hulusipolat $44 @ g$ mail.com
}

Case suffixes form various meaning relations in the sentence. The semantic and syntactic functions of the morphological aspects of the case suffixes should also be considered. These suffixes, whose actual functions appear in syntactic structure, serve as subjects, objects and complementary functions in the sentence. Orkhon inscriptions, which is one of the first written documents of Turkish, is an important source in the study of the grammatical development of the Turkish language. In order to determine the usage and functionality of the case suffixes in the historical period, the case suffixes used in the Orkhon inscriptions were examined in this study.

Key Words: case suffixes, Orkhon inscriptions, syntactic function. 


\section{$J(\Theta)$}

\section{Giriş}

Dilbilgisi çalışmalarında genellikle eklerin morfolojik yönü üzerine durulması ve sentaktik işlevlerinin ikinci planda kalması, metinlerin çözümlenmesinde sıkıntılara yol açmaktadır. Durum eklerinin işlevleri sözcük grupları ve cümle yapısı içinde belirlendiği için durum ekleri morfo-sentantik yönden incelenmelidir.

Hâl ekleri ismi kendisine tabi olmayan, kendisinin tabi olduğu unsurlarla münasebetini kuran eklerdir. Hâl ekleri ileriye doğru münasebet kuran kelime grupları ve cümlelerde yardımcı unsurları esas unsurlara bağlayan eklerdir (Ergin 2009: 227).

DALLI, hal eklerinin topluca aynı zamanda değil, farklı farklı zaman dilimleri içinde, dilde gereksinimler ortaya çıtıkça oluşup geliştiğini, hal şekillerinin çoğunlukla tek anlamlı olup çok işlevli özelliklerini eski dilden beri sürdürdüklerini, çok işlevli olmaları nedeniyle sınırsız varlık bağıntılarını dile getirdiklerini belirtmiştir (2018: 40). Kimi “tarihî” durum ekleri kalıplaşmış, yapım eki işlevi kazanmış olarak yaşamaktadır. Yani durum eklerinin sayısı zamana bağlı olarak değişebilmektedir (Eker 2010: 336).

ERGiN, durum eklerini, nominatif hali (yalin), genitif hali (ilgi), akuzatif hali (yapma), datif hali (yaklaşma), lokatif hali (bulunma), ablatif hali (uzaklaşma), enstrumental hali (vasita), ekvatif hali (eşitlik) ve direktif hali (yön gösterme) olarak tasnif etmiştir (2009: 227-228).

BANGUOĞLU, durum eklerini sözdizimindeki işlekliklerine göre iççekim halleri (kim hali, kimi hali, kime hali, kimde hali, kimden hali, kimin hali) ve dışçekim halleri (kimle hali, kimce hali, kimli hali, kimsiz hali) olarak iki gruba ayırmıştır (1990: 326).

Yapılan gramer çalışmalarında durum ekleri genelde morfolojik açıdan ele alınmış ve tanımlanma ve sınıflama buna bağlı olarak gelişmiştir. Genel sınıflamadan ayrı olarak Alyılmaz 1994 ve Mert 2002 çalışmalarında eklerin işlevlerini de dikkate alarak durum eklerini belirten, belirtilen, nesne, bulunma, ayrılma, çıkışllık, yönelme, birliktelik-beraberlik, karşıllkhllk, hedef, sebep, vasita, görelik, nasilllk, nice- 


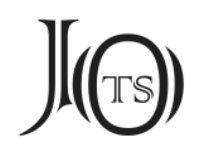

lik, karşılaştırma, sınırlandırma, benzetme, seslenme gibi farklı sınıflandırmalarda incelemişlerdir. Gramer çalışmalarında tam olarak terim birliğine varılmadığı için bu tarz adlandırmaların konuyu daha da zorlaştıracağı düşüncesiyle çalışmada genel kabul gören yalın, belirtme, yönelme, bulunma, ayrlma, yön gösterme, araç, eşitlik ve ilgi terimleri kullanılmıştır.

Sentaktik işlevde durum ekli ad, bitmiş eyleme bağlanarak temel önermenin öznesi, nesnesi, tümleci olur veya eylemsiye bağlanarak yan önermenin öznesi, nesnesi, tümleci olur (Üstünova 2012: 61). Görevleri sözdizimsel olan bu ekler, tümce içi ilişkileri düzenler (Demircan 2005: 101).

Çalışmamızdaki yazıtlardan örnekler Aydın 2017a'dan alınmıştır.

\subsection{Yalın Durumu}

Yalın durumu, ek almayan adın özne durumudur. Adın herhangi bir sonek almamış, yalın olduğu durumudur (Aksan 2009: 91). Kimi kaynaklarda belirtisiz ad tamlamalarında tamlayanın, sözde öznenin ve belirtisiz nesnenin, sıfatların, zarfların yalın durumda olduğu ileri sürülse de bu görüşlere katılmak mümkün değildir (Üstünova 2012: 168). Yanlış anlaşılmayla “yalın” terimi, ek almayan gramer yapılarını da içine almıştır. Sentaktik yapıda yalın durum sadece özne işlevi görmektedir:

ol amtı añıg yok “Onlar şimdi kötü (durumda) değiller.” (KT G3)

bilig bilmez kişi ol sawıg alıp yagru barıp üküş kişi öltüg "Bilgisiz (cahil) kişi(ler) o sözü (dikkate)

alıp yakına varıp çok (sayıda) kişi öldünüz.” (KT G7)

türük bodun tokurkak sen "Türk halk1 sen toksun." (KT G8)

men beygü taş tikdim "Ben ebedi taş diktim.” (KT G11)

tawgaç kaganı̇ içreki bedizçig $<$ d>tı "Çin kağanı, has süsleme ustasını gönderdi." (KT G12)

tört buluy kop yagı ermiş "Dört taraf hep düşmanmış." (KT D2)

begleri yeme bodunı yeme tüz ermiş "Beyleri de halkı da doğru imiş." (KT D3)

buyrukı yeme biligsiz <ermiş> erinç yawlak ermiş erinç "Komutanları da bilgisizmiş elbette, kötüymüş elbette." (KT D5)

kayım kagan yéti yégirmi erin taşıkmış "Babam kağan on yedi adamıyla isyan etmiş." (KT D11 $=\mathrm{BK}$ D10) 


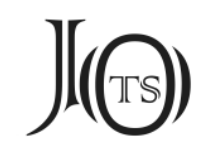

balıdakı taşıkmış tagdakı énmiş "Kenttekiler dağa çıkmış (isyan etmiş), dağdakiler inmiş." (KT D12)

eçüm apam törösinçe yaratmış boşgurmış "Atalarım, dedelerim yasalarına göre (uygun olarak) yeniden örgütlemiş, eğitmiş (öğretmiş).” (KT D13 = BK D12)

berye tawgaç bodun yagı ermiş "Güneyde Çin halkı düşmanmış." (KT D14 = BK D12)

töröde üze éçim kagan olortı "Yasalar gereğince amcam kağan tahta oturdu." (KT D16 = BK D14)

buyrukı begleri yeme ölti “Komutanları, beyleri de öldü.” (KT D19)

özi yayıltı kaganı ölti bodunı kün kul boltı "Kendisi yanıldı, kağanları̈ öldü, halkı cariye (ve) köle oldu." (KT D20)

kanıy suwça yügürti sünüküy tagça yatdı "Kanlarınız su gibi aktı, kemikleriniz dağ gibi yığıldı." (KT D24)

bunça törög kazganip inim köl tégin özi ança kergek boltı "Bunca yasaları kazanıp kardeşim Köl Tégin öldü." (KT D30)

yaşıya éçim kagan elin törösin ança kazgantı "Amcam kağan yurdunu, yasalarını öylece elde etti." (KT D31)

köl tégin yadagın oplayu tegdi “Köl Tégin yaya olarak ileri atıldı." (KT D32)

ol at anta ölti "O at orada öldü." (KT D33)

ulug érkin azkiña erin tezip bardı "Ulug Erkin azıcık adamıyla kaçıp gitti." (KT D34)

kara türgéş bodun kop içikdi "Kara Türgeş halkı tamamen tabi oldu." (KT D38)

az bodun anta yok bolt t "Az halkı orada yok oldu." (KT K3)

köl tégin azman akıg binip oplayu tegdi "Köl Tégin azman ak atına binip ileri atılıp saldırdı." (KT K5)

oguz yagı ordog basdı "Düşman Oğuzlar karargâhı bastı." (KT K8)

inim köl tégin kergek boltı "Kardeşim Köl Tégin öldü.” (KT K10)

udar seyün kelti "General Udar geldi." (KT K12)

kırkız kaganta tarduş ınançu çor kelti “Kırgız kağanından Tarduş Inançu Çor geldi.” (KT K13)

eçüm apam bumın kagan istemi kagan olormış "Atalarım, dedelerim Bumın Kağan (ve) İstemi Kağan tahta oturmuş." (BK D3)

tört bulug kop yagı ermiş “Dört taraf hep düşmanmış." (BK D3)

özi ança kergek bolmış “Kendisi öylece ölmüş.” (BK D4)

inisi kagan bolmış eri]nç "Oğulları kağan olmuş elbette." (BK D5)

türük kara kamag bodun ança témiş "Türk (avam) halkı şöyle demiş." (BK D8) 


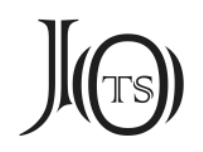

taw[gaç o]y totok béş̧ tümen sü kelti “Çinli askeri vali Ong, elli bin askerle geldi.” (BK D25)

üç oguz süsi basa kelti “Üç Oğuz ordusu baskın yaptı.” (BK D32)

türük bodun ölteçi erti yok boltaçı erti “Türk halkı ölecekti, yok olacaktı.” (BK D33)

türk bodun tawgaçka körür erti “Türk halkı Çin’e tabi idi.” (T1 B1)

taşda kalmışı kuwranıp yéti yüz boltı "Yazıda yabanda kalanlar toplanıp yedi yüz (kişi) oldular." (T1 B4)

bodun bogzı tok erti “Halkın karnı toktu.” (T1 G1)

oguzduntun küreg kelti “Oğuzlardan kaçak geldi.” (T1 G1)

kaganı alp ermiş ayguçısı bilge ermiş "Kağanı kahramanmış, danışmanı bilgeymiş." (T1 G3)

oguz kopın kelti “Oğuzların tamamı (üzerimize) geldi.” (T1 G9)

béryeki bodun kurıyakı yıryakı öyreki bodun kelti "Güneydeki halklar, batıdaki, kuzeydeki, doğudaki halklar geldiler." (T1 G10)

küçlüg kagan yagımız boltı Küçlüg Kağan düşmanımız oldu. (T1 D3)

türgéş kagan ança témiş “Türgeş kağanı şöyle demiş.” (T1 D4)

kögmen yolı bir ermiş “Kögmen'in yolu bir tane imiş.” (T1 D6)

kaganı alp ermiş ayguçısı bilge ermiş "Kağanı kahramanmış, danışmanı bilgeymiş." (T1 K5)

tawgaç süsi bar ermiş “Çin ordusu (oraya) varmış." (T1 K6)

tegri umay ıdok yér suw basa bérti erinç "Kutsal Umay (ve) kutsal yer su (ruhları) yardım etti, elbette." (T2 B3)

sogdak bodun kop kelti yükünti “Soğd halk1 tamamen geldi (ve) itaat etti.” (T2 G2)

türük bilge kagan türük sir bodunug oguz bodunug igidü olorur "Türk Bilge Kağan Türk Sir halkını, Oğuz halkını besleyerek tahtta oturur." (T2 K4)

\subsection{Belirtme Durumu}

İyelik eksiz gövdelerde $\{+(\mathrm{X}) g\}$, iyelik ekli gövdelerde $\{+(\mathrm{I}) \mathrm{n}\}$ biçimindedir. Çok seyrek olarak da $\{+$ nI\} eki kullanılır (Tekin 2016: 102). Ayrıca $\{+I\}$ kullanımı da vardır. Kökleri /n/ ile biten zamirlere, yükleme halinde sadece $\{+$ i $\}$ ilave edilir (Grønbech 2011: 124). Kelime gruplarında ve cümlelerde fiilin doğrudan doğruya tesir ettiği isimler akuzatif halinde bulunur (Ergin 2009: 231). Belirtme durumu için, "yükleme" ve "akuzatif" terimleri de kullanılmıştır. Belirtme durumu sentaktik yapıda belirtili nesne işlevi görür. Yükleme halinin kullanılışı, daima kelimelerin yeriyle ilgili bağlam içinde incelenmelidir (Grønbech 2011: 128). 


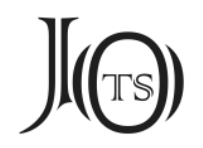

Türkçede nasıl özne için varsayılan durum eki yalın durum ise fiilin nesnesi için de belirtme durumu varsayılan (default) durum ekidir. Fiile bağlı unsurların durum ekleriyle işaretlenmesi genellikle gramatikal veya sentaktik durum (syntactic case) olarak bilinir (Erdem 2015:170).

\subsection{1. $\{+(\mathrm{X}) \mathrm{g}\}$}

İyelik eksiz gövdelere gelen belirtme ekidir.

\subsubsection{Belirtili Nesne İşlevi}

süçig sawın yımşak agın arıp ırak bodunug ança yagutır ermiş "Tatlı sözle, yumuşak ipeklerle kandırıp uzaktaki halkları öylece (kendine) yaklaştırırmış.” (KT G5)

edgü bilge kişig edgü alp kişig yorıtmaz ermiş "İyi akıl sahibi kişileri, iyi kahraman kişileri ilerletmezmiş." (KT G6)

bilig bilmez kişi ol sawıg alıp yagru barıp üküş kişi öltüg "Bilgisiz kişiler o sözü dikkate alıp yakına varıp çok sayıda kişi öldünüz." (KT G7)

yok çıgañ bodunug kop kuwratdım "Yoksul halkı tamamen derleyip toparladım." (KT G10)

çıgañ bodunug bay kıltım "Yoksul halkı zengin ettim." (KT G10)

az bodunug üküş kıltım “Az halkı çoğalttım.” (KT G10)

tawgaç kaganıฑ içreki bedizçig $\imath<d>t \imath$ "Çin kağanı, has süsleme ustasını gönderdi." (KT G12

tört buluydakı bodunug kop almış kop baz kılmış "Dört taraftaki halkları hep ele geçirmiş, tabi etmiş." (KT D2)

anı üçün élig ança tutmış erinç “Onun için ülkeyi öylece sahiplenmişler elbette.” (KT D3)

elig yıl işig küçüg bérmiş "Elli yıl işi gücü vermişler, hizmet etmişler.” (KT D8)

ne kaganka işig küçüg bérür men ter ermiş "Hangi kağana işi gücü veriyorum (hizmet ediyorum) dermiş." (KT D9)

kayım élteriş kaganıg ögüm élbilge katunug tẹri töpösinte tutup yügerü kötürmiş "Babam Elteriş Kağan'1, annem Elbilge Hatun'u (ebedi) gök, tepelerinden (?) tutup (göğe) yükseltmiş.” (KT D11)

élsiremiş kagansıramış bodunug küyedmiş kuladmış bodunug türük törösin ıçgınmış bodunug eçüm apam törösinçe yaratmış boşgurmış "Yurtsuz bırakılmış, kağansız bırakılmış halkı, cariye (ve) köle olmuş halkı, Türk yasalarını kaybetmiş halkı atalarım, dedelerim yasalarına göre (uygun olarak) yeniden örgütlemiş, eğitmiş." (KT D13)

tölis tarduş bodunug anta etmiş “Tölis (ve) Tarduş halklarını orada örgütlemiş.” (KT D13)

yawgug şadıg anta bérmiş "Yabgu (ve) şad (unvanlarını) orada vermiş.” (KT D14) 
élligig élsiretmiş kaganlıgıg kagansıratmış "Yurdu olanı yurtsuz bırakmış, kağanı olanı kağansız bırakmıs.." (KT D15)

yagıg baz kılmıs "Düşmanı tabi etmiş." (KT D15)

törög kazganıp uça barmış "Yasaları kazanıp (sonsuzluğa) uçup gitmiş." (KT D16)

baz kaganıg balbal tikmiş “Baz Kağan'ı balbal (olarak) dikmişler.” (KT D16)

türük bodunug yiçe etdi “Türk halkını yeniden düzenledi.” (KT D16)

élligig élsiretdimiz “Yurdu olanı yurtsuz bıraktık." (KT D18)

kaganlıgıg kagansıratdımız “Kağanı olanı kağansız bıraktık.” (KT D18)

ilgerü kadırkan yışıg aşa bodunug ança konturtumuz "Doğuda Kadırkan (ormanlı) Dağları'nı aşarak halkı öylece yerleştirdik." (KT D21)

türük bodunug ança konturtumuz “Türk halkını öylece yerleştirdik.” (KT D21)

kırkız kaganıg balbal tikdim "Kırgız kağanını balbal diktim.” (KT D25)

kayım kaganıg ögüm katunug kötürmiş tegri él bérigme tegri "Babam kağanı, annem hatunu yükselten (ebedi) gök, yurdu veren (ebedi) gök.” (KT D25)

ança kazganıp birki bodunug ot suw kılmadım "Öylece elde edip birleşik halkları ateş (ve) su gibi (birbirlerine) düşman etmedim.” (KT D27)

bodunug igideyin téyin "Halkı besleyeyim diye." (KT D28)

ölteçi bodunug tirgürü igit<d>im “Ölmek üzere olan halkı diriltip besledim.” (KT D29

yalag bodunug tonlug <kltım> çıgañ bodunug bay kıltım az bodunug üküş klltım "Sırtı açıkta olan halkı giydirdim, yoksul halkı zengin ettim, az halkı çoğalttım.” (KT D29)

bodunug kop baz kiltım "Halkı tamamen tabi kıldım." (KT D30)

işig küçüg bérür “iş̧lerini, güçlerini verirler.” (KT D30)

bunça törög kazganıp inim köl tégin özi ança kergek boltı "Bunca yasaları kazanıp kardeşim Köl Tégin öldü." (KT D30)

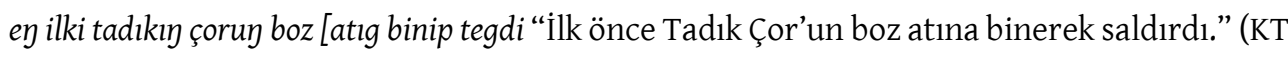
D32)

ékinti ışwara yamtar boz atıg binip tegdi “ikinci olarak Işvara Yamtar'm boz atına binerek saldird.." (KT D33)

kırkız bodunug uda basdımız "Kırgız halkını uykuda (iken) baskına uğrattık." (KT D35)

bir erig okın urtı "Bir askeri okuyla vurdu." (KT D36)

éki erig udşuru sançdı “iki askeri takip edip mızrakladı.” (KT D36)

bayırkunuy ak adgırıg udlıkın slyu urtı "Bayırku'nun ak aygırını uyluğundan vurup kırdılar." (KT D36) 


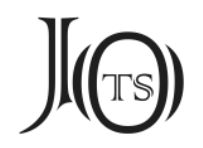

toga ertiş ügüzüg keçe yorıdımız “İrtiş Irmağı’nı geçerek ilerledik.” (KT D37)

türgéş bodunug uda basdımız "Türgeş halkını uykuda (iken) baskına uğrattık.” (KT D37)

türgéş kagan buyrukı az totokug eligin tutdı "Türgeș kağanının komutanlarını (ve) Azların askeri valisini eliyle yakaladı." (KT D38)

yénçü ügüzüg keçe temir kapıgka tegi süledimiz “Inci (Sirderya) Irmağı'nı geçip Demir Kapı'ya kadar sefer ettik." (KT D39)

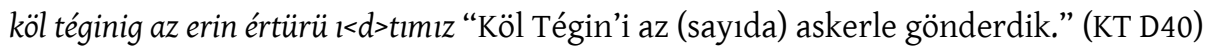

kara türgéş bodunug anta ölürmiş almış "Kara Türgeş halkını orada öldürmüş, ele geçirmiş." (KT D40)

éki erig udşuru sançdı “iki askeri kovalayarak mızrakladı.” (KT K2)

karlokug ölürtümüz altımız "Karlukları yok ettik, ele geçirdik.” (KT K2)

az éltewerig tutdı “Azların elteverini yakaladı.” (KT K3)

altı erig sançdı "Altı askeri mızrakladı." (KT K5)

oplayu tegip bir erig sançdı "ileri atılıp saldırıp bir askeri mızrakladı." (KT K5)

tokuz erig egire tokıdı "Dokuz askeri, etrafını sararak mahvetti." (KT K6)

tonra bir uguş alpagu on erig tona tégin yoginta egirip ölürtümüz "Tongralardan bir grup kahraman (ile) on askeri Tonga Tégin'in cenaze töreninde çevirip öldürdük.” (KT K7)

éki erig sançdı "iki askeri mızrakladı.” (KT K8)

oguz yagı ordog basdı "Düşman Oğuzlar karargâhı bastı.” (KT K8)

ordog bérmedi "Karargâhı vermedi." (KT K9)

bilmez kişi ol sawig alp yagru barı üküş kişi öltüg "Bilmez (cahil) kişi o sözü alıp yakınlaştığında çok sayıda kişi öldünüz." (BK K6)

kagan olorup yok çıgañ bodunug kop kuwrat<d $>l m$ "Tahta otorup yoksul halkı tamamen derleyip toparladım." (BK K7)

çıañ bodunug bay klttım "Yoksul halkı zengin ettim." (BK K7)

az bodunug üküş kltım “Azhalkıçoğalttım.” (BK K7)

türük bodunug terip él tutsıkının bunta urtum "Türk halkını bir araya getirip ülke kuracağını buraya kazıdım (yazdım)." (BK K8)

bunça agır törög tört buluydakı yarat<d>ım bitidim "Bunca önemli yasayı, dört taraftaki (halkı) düzene soktum, (bunları) yazdım." (BK D2)

sü sülepen tört buluydakı bodunug baz kıl[mış] "Ordu sevk ederek dört taraftaki halkları tabi etmiş." (BK D3)

[anı] üçün elig ança tutmış erinç "Onun için ülkeyi öylece sahiplenmişler elbette." (BK D4) 


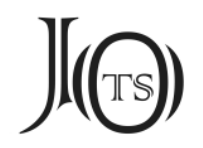

işig küçüg bérmiş “iş̧i gücü vermişler (hizmet etmişler).” (BK D8)

ne kaganka işig küçüg bérür men tér ermiş "Hangi kağana hizmet ediyorum? dermiş." (BK D9)

bunça işig küçüg bértök<g>erü sakınmatı "Bunca hizmet ettiğini düşünmeden” (BK D9)

kayım éltériş kaganı ögüm élbilge katunug teyri töpösinte tutup yügerü kötürti "Babam Elteriş Kağan'ı annem Elbilge Hatun'u (ebedi) gök, tepelerinden tutup (göğe) yükseltmiş.” (BK D10)

tölis tarduş bodunug anta étmiş "Tölis (ve) Tarduş halklarını orada örgütlemiş." (BK D12)

yawgug şadıg anta bérmiş "Yabgu (ve) şad (unvanlarını) orada vermis." (BK D12)

kaganlıgıg kagansıratmış “Kağanı olanı kağansız bırakmış." (BK D13

yagıg baz kılmış "Düşmanı tabi kılmış." (BK D13)

kayım [kaganka] başlayu baz kaganıg balbal tik[miş “Babam kağana ilk önce BazKağan’ıbalbal (olarak) dikmişler." (BK D13)

olorupan türük bodunug yiçe étdi yiçe igit<d>i "Tahta çıktığında Türk halkını yeniden örgütledi, yeniden besledi." (BK D14)

çıgañıg bay klltı "Yoksulu zengin etti." (BK D14)

azıg üküş kıltı “Az (halkı) çoğalttı.” (BK D14)

kaganlıgıg kagansıratdımız "Kağanı olanı kağansız bıraktık.” (BK D15)

kagan atıg bunta biz bértimiz "Kağan unvanını burada biz verdik." (BK D17)

sipilim kunçuyug bértimiz “Kız kardeşim prensesi (eş olarak) verdik.” (BK D17)

türük bodunug ança konturtumuz ança étdimiz "Türk halkını öylece yerleştirdik, öylece düzenledik." (BK D18)

birki bodunug ot suw klmadım "Birleşik halkları ateş (ve) su gibi (birbirine) düşman etmedim." (BK D22)

yalay bodunug tonlug klttım "Sırtı açıkta olan halkı giydirdim." (BK D23)

çıgañ bodunug bay kıltım "Yoksul halkı zengin ettim.” (BK D23)

az bodunug üküş kıltım “Az halkı çoğalttım.” (BK D24)

tagut bodunug buzdum "Tangut halkını bozguna uğrattım." (BK D24)

bodunug anta buzdum "Halkını orada bozguna uğrattım." (BK D25)

kırkız bodunug uda basdım "Kırgız halkını uykuda (iken) baskına uğrattım.” (BK D27)

türgéş bodunug] uda basdım "Türgeş halkını uykuda (iken) baskına uğratıı." (BK D27)

karlok badunug ölürtüm “Karluk halkını yok ettim.” (BK D29)

tugla ügüzüg yüzüti keçip “Tula Irmağı’nı yüzdürerek geçip” (BK D30) 


\section{$J(\Theta)$}

anta toyra yılpagutı bir uguşug tona tégin yog[inta] egire tokıdım "Orada Tongralardan bir kahraman grubunu Tonga Tégin'in cenaze töreninde yok ettim.” (BK D31)

slıar süsi ewig barkıg yulıgalı bardı "Ordunun yarısı evi barkı yağmalamaya gelmişti." (BK D32)

ol yılkıg alıp igit<d>im “O hayvan sürülerini alıp besledim." (BK D38)

bodunug anta buzdum "Halkını orada dağıttım." (BK D39)

tudun yamtarıg $1<d>$ tım bardl “Tudun Yamtar'ı gönderdim, gitti." (BK D40)

kök öyüg yoguru sü yorıp tünli künli yéti ödüşke suwsuz keçdim “Kök Öng (Ongi) Irmağı'nı (bata çıka) aşıp orduyu yürütüp geceli gündüzlü yedi gün boyunca susuz olarak geçtim." (BK GD)

bir tümen artukı yéti bin süg ilki kün ölürtüm "On yedibin kişilik ordusunu ilk gün yok ettim." (BK G1)

üç tümen süg [ölür]tüm “Otuz bin askerini öldürdüm.” (BK G8)

kug seyünüg balbal tike bértim “General Ku’yu balbal (olarak) dikiverdim.” (BK G9)

yog yıparıg kelürüp tike bérti “Cenaze tütsüleri getirip dikiverdiler." (BK G11)

yéti yüz kişig uduzugma ulugı şad erti "Yedi yüz kişiyi sevk edenlerin lideri şad (unvanlı) idi." (T1 B4-5)

bérye tawgaçıg öyre kıtañıg yırya oguzug üküş ök ölürti "Güneyde Çinlileri, doğuda Kitanlıları, kuzeyde Oğuzları çokça mahvetti." (T1 B7)

çugay kuzın kara kumug olorur ertimiz “Çugay Kuzı ile Kara Kum'u yurt tutmuştuk.” (T1 B7)

kıtañgaru togra eşimig ıdmış “Kitanlılara Tongra Eşim’i göndermişler.” (T1 G2)

tawgaçgaru kunı seyünüg ıdmış “Çin’e General Ku'yu göndermişler.” (T1 G2)

ol éki kişi bar erser sini tawgaçıg ölürteçi ter men "O ikisi var olduğu sürece seni, (yani) Çinlileri öldürecektir, derim.” (T1 G3)

bini oguzug ölürteçik tér men "Beni (yani) Oğuzları öldürecektir, derim.” (T1 G3-4)

ol sawı géşidip tün udısıkım kelmedi "O sözleri işitince gece uyuyasım gelmedi” (T1 G5)

kök öyüg yoguru ötüken yışgaru uduztum “Kök Öng (Ongi) Irmağı'nı (bata çıa) aşıp (orduyu) Ötüken (ormanlı) Dağları'na doğru sevk ettim.” (T1 G8)

atıg ıka bayur ertimiz "Atları ağaçlara bağlıyorduk." (T1 K3)

kırkızıg uka basdımız "Kırgızları uykuda (iken) baskına uğrattık." (T1 K3)

kögmen yışıg ewirü keltimiz “Kögmen (ormanlı) Dağları'nı dolanarak geldik.” (T1 K4)

bo süg élet tédi "Bu orduyu sevk et, dedi." (T1 K8)

kıyınıg köglüyçe ay “Cezaları da uygun gördüğün şekilde ver.” (T1 K8) 


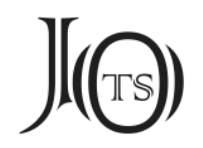

ol sawıg éşidip kagangaru ol sawı l<d>tım "O sözleri işitip kağana, bu bilgiyi ilettim." (T1 K9)

ol sawıg éşidip sü yorıtdım "O sözü işitip ordu sevk ettim.” (T1 K11)

ertiş ügüzüg keçigsizin keçdimiz “İrtiş Irmağı’nın geçilemeyecek yerlerini geçtik.” (T1 K11)

altun yışıg yolsızın aşdım<ız "Altay (ormanlı) Dağları'nın yolu olmayan yerlerini aştık." (T1

K11)

thlıg kelürti “Casusu getirdiler.” (T2 B1)

ertiş ügüzüg keçe keltimiz “İrtiş Irmağı'nı geçerek geldik.” (T2 B2-3)

işig küçüg bértim “issi gücü verdim (hizmet ettim).” (T2 D2)

ök uzun yelmeg yeme $k$ d>tım ok "Uzaklara öncü birlikleri de gönderdim." (T2 D2)

arkuy karagug ulgartdım “Karakol (gözetleme) kuleleri diktirdim.” (T2 D3)

ok yanıgma yagıg kelürür ertim “Geri dönen düşmanları getirttim.” (T2 D3)

bo türük bodun ara yaraklıg yagıg yeltürmedim "Bu Türk halkı arasına silahlı düşmanı sokmadım." (T2 D4)

tügünlüg atıg yügürtmedim “(Kuyruğu) düğümlü atları koşturtmadım.” (T2 D4)

türük sir bodunug oguz bodunug igidü olorur "Türk Sir halkını, Oğuz halkını besleyerek tahtta oturur." (T2 K4)

\subsubsection{Dolaylı Tümleç İşlevi}

başlıgıg yüküntürmiş tizligig sökürmiş "Mağrurlara baş eğdirmiş, asilere diz çöktürmüş." (KT D2)

tizligig sökürmiş başlıııg yüküntürmiş "Asilere diz çöktürmüş, mağrurlara baş eğdirmiş." (KT D15)

tizligig sökürtümüz başlgııg yüküntürtümüz "Asilere diz çöktürdük, mağrurlara baş eğdirdik." (KT D18)

başlgııg yüküntürmiş tizlig[ig sökürmiş "Mağrurlara baş eğdirmiş, asilere diz çöktürmüş." (BK D3)

başlıııg yüküntürtümüz “Mağrurlara baş eğdirdik.” (BK D16)

\subsection{2. $\{+(\mathrm{I}) \mathrm{n}\}$}

İyelik ekli gövdelere gelen belirtme ekidir. Üçüncü kişi iyelik ekinin yapısını bir grup dilci $\{+(s) I\}$, başka bir grup $\{+(\mathrm{s}) \mathrm{I}(\mathrm{n})\}$ olarak göstermektedir. $\{+(\mathrm{s}) \mathrm{I}(\mathrm{n})\}$ yapisını kabul edenler belirtme halini eksiz kabul etmektedirler. $\{+(\mathrm{s}) \mathrm{I}(\mathrm{n})\}$ yapısını kabul eden BAŞDAŞ, yapının bazen iyelik kavramını taşımadan sadece belirtme 
görevi üstlendiğini belirtmiştir (2009: 640). KERIMOĞLU ise, \{+(I)n\} ekinin hem iyelik hem de belirtme işlevleriyle iki görevli kullanımına dikkat çekmiştir (2007: 329). Çalışmamızda işlevinden dolayı belirtme eki olarak gösterilmiştir.

\subsubsection{Belirtili Nesne İşlevi}

sawımın tüketi éşidgil "Sözlerimi sonuna kadar işit.” (KT G1)

bo sawımın edgüti esşid katıgdı tııla "Bu sözlerimi iyice işit (ve) sıkıca dinleyin.” (KT G2)

igidmiş kaganııın sawın almatın yér sayu bardıg "(Seni) beslemiş kağanının sözlerini (dikkate)

almadan her yere gittin." (KT G9)

él tutsıkının bunta urtum “Ülke kuracağınızı buraya kazıdım (yazdım).” (KT G10)

yayılıp ölsikinin bunta urtum "Yanılıp öleceğinizi de buraya kazıdım (yazdım)." (KT G10-11)

meniy sawımın sımadı "Benim sözümü kırmadı." (KT G11)

için taşın adınçıg bediz urturtum "İçini, dışını muhteşem (şekilde) süslettim.” (KT G12)

köyülteki sawımın urturtum "Gönlümdeki sözlerimi nakşettim.” (KT G12)

türük bodunıy élin törösin tuta bérmiş éti bérmiş “Türk halkının ülkesini (ve) yasalarını tutuvermiş, düzenleyivermişler." (KT D1)

élledök élin ıçgınu ıdmış "Yurt tuttuğun toprakları elinden almış." (KT D6)

kaganladok kaganın yitürü ıdmış "Kağan yaptığı kağanını kaybetmiş.” (KT D7)

türük begler türük atın $k<d>t \imath$ "Türk beyleri Türk unvanlarını bıraktı." (KT D7)

tawgaç kaganka élin törösin alı bérmiş "Çin kağanına ülkesini, yasalarını alıvermişler." (KT D8)

türük bodun élinin törönün kim artatı "Türk halkı! Yurdunu (ve) yasalarını kim bozabilirdi?" (KT D22)

altı yégirmi yaşına éçim kagan elin törösin ança kazgantı "On altı yaşında, amcam kağan yurdunu, yasalarını öylece elde etti." (KT D31)

oy totok yurçın yaraklıg eligin tutdı "Ong Totok'un kaynını, silahlı (olduğu halde) eliyle yakalad1." (KT D32)

kırkız kaganın ölürtümüz élin altımız "Kırgız kağanını öldürdük. Yurdunu aldık.” (KT D36)

ékisin özi altızdı "İkisini kendi ele geçirdi.” (KT D38)

türgéş kagan buyrukı az totokug eligin tutdı “Türgeş kağanının komutanlarını (ve) Azların askeri valisini eliyle yakaladı." (KT D38)

kaganın anta ölürtümüz élin altımız “Kağanını orada öldürdük. Yurdunu aldık.” (KT D38)

alp salçi ak atın binip tegmiş "Alp Salçi'nin ak atına binip saldırmış.” (KT D40)

erin kop ölürmiş “Askerlerini tamamen öldürmüş.” (KT K1) 


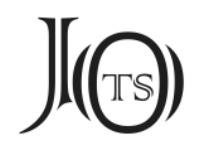

alp salçi akın binip oplayu tegdi “Alp Salçi'nin ak atına binip ileri atılıp saldırdı." (KT K2)

süsin sançdımız élin altımız "Ordusunu mızrakladık. Yurtlarını ele geçirdik.” (KT K6)

az yagızın binip tegdi “Az yağız (atına) binip saldırdı.” (KT K8)

ögsüz akın binip tokuz eren sançdı “Öksüz ak atına binip dokuz askeri mızrakladı.” (KT K9)

barkın bedizin bitig taşın béçin yılka yétinç ay yéti otuzka kop alkdımız "Anıt mezarını, süslemelerini, yazıt taşını, maymun yılının yedinci ayının yirmi yedisinde tamamen bitirdik.” (KT K-D)

köl téginin altunın kümüşin agısın barımın tör[t bın yıl] kısın ayıgma toygut "Köl Tégin'in altınını, gümüşünü, ipeklilerini, varlığını, dört bin (baş) hayvan sürüsünü söyleyen (anlatan) Toygut" (KT G-B)

sawımın tüketi éşid "Sözlerimi sonuna kadar dinle." (BK K1)

bo sawımın edgüti esşid katıgdı tı̊la "Bu sözlerimi iyice işit (ve) sıkıca dinleyin." (BK K1)

kızın ertiyü ulug törön ogluma alı bértim "Kızını pek büyük törenle oğluma alıverdim." (BK K10)

sarıg altu ]nın ürüy kümüşün kırkaglg kotayın kinlig işgitisin özlük atın adgırın kara k[işin] kök teyenin türüküme bodunuma kazganu bértim eti bértim "Sarı altını, beyaz gümüşü, kenarlı ipeklileri, misk kokulu ipeklileri, has atları, aygırları, kara samurları boz dağ sıçanı (derilerini) Türklere (tabi) halkım için kazandım, elde ettim." (BK K11)

sawımın sımadı "Benim sözümü kırmadı." (BK K14)

için taşın adınçıg bediz u[rturtu]m "İçini, dışını muhteşem şekilde süslettim." (BK K14)

olorupan türük bodunıy élin törösin tuta bérmiş eti bérmiş "Tahta oturup Türk halkının ülkesini (ve) yasalarını tutuvermiş, düzenleyivermiş.” (BK D3)

élledök élin ıçgınu ıdmış "Yurt tuttuğun toprakları elinden almış." (BK D7)

kaganladok kaganın yitürü ıdmış “Kağan yaptı̆̆ı kağanını kaybetmiş." (BK D7)

türük begler türük atın $<d>t l$ "Türk beyleri Türk unvanlarını bıraktı." (BK D7)

tawgaç kaganka élin tör<ö>sin alı bérmiş “Çin kağanı için ülkesini, yasalarını alıvermişler." (BK D8)

inisi éçisin bilmez erti “Kardeş, ağabeyini bilmezdi.” (BK D18)

ogh kanın bilmez erti “Çocuklar babasını bilmezdi.” (BK D18)

türük bodun élinin törögin kim artatı udaçı erti “Türk halkı! Yurdunu (ve) yasalarını kim bozabilirdi?" (BK D19)

özümün ol tegri kagan olortdl "Beni, o (ebedi) gök tahta oturttu." (BK D21)

oglın yu[tuz] In yılkısın barımın anta altım "Çocuklarını, karılarını, hayvan sürülerini, varlıklarını orada ele geçirdim." (BK D24) 


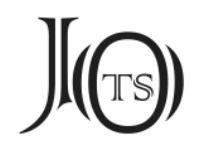

süsin anta ölürtüm “Ordusunu orada yok ettim.” (BK D26)

süsin sançdım "Ordusunu mızrakladım." (BK D26)

élin anta altım "Ülkesini orada ele geçirdim." (BK D27)

kaganın ölürtüm “Kağanını öldürdüm.” (BK D27)

élin anta altım “Ülkesini orada ele geçirdim.” (BK D28)

süsin sançdım "Ordusunu mızrakladım." (BK D30)

oza yaña keligme süsin agıt<d>ım "Kurtularak dağılıp gelen ordusunu püskürttüm.” (BK D31)

süsin anta sançdım yawrıtdım "Ordusunu orada mızrakladım, (ordusunu) zayıf düşürdüm." (BK D31)

ewin barkın buzdum "Evinibarkınıyıktım." (BK D34)

süsin buzdum élin anta altım “Ordusunu dağıttım, ülkesini orada ele geçirdim.” (BK D34)

tokuz oguz bodun yérin suwın ıdıp tawgaçgaru bardı "Dokuz Oğuz halkı topraklarını bırakıp Çin'e gitti." (BK D35)

süsin sançdım “Askerlerini mızrakladım.” (BK D 37)

karagan kıslta ewin barkın anta buzdum "Evini barkını orada yıktım.” (BK D37)

oglın yutuzın anta altım "Çocuklarını, karılarını orada ele geçirdim." (BK D38)

yutuzın yok kıltım "Karılarını yok ettim." (BK G4)

alp erin ölürüp balbal kllu bértim "Kahraman askerini öldürüp balbal (olarak) dikiverdim." (BK G7)

bunça bodun saçın kulkakın bıçdı "Bunca halk saçını, kulağını kesti.” (BK G12)

edgü özlük atın kara kişin kök teyenin sansız kelürüp kop ko<d>tı "Iyi has atlarını, kara samurları (ve) boz dağ sıçanı (derilerini) sayısızca getirip bıraktılar." (BK G12)

kanın kodup tawgaçka yana içikdi “Hanını bırakıp Çin'e yeniden tabi oldu.” (T1 B2)

kanııın kodup içikdi» "Hanını bırakıp tabi oldun.” (T1 B3)

çugay kuzın kara kumug olorur ertimiz “Çugay Kuzı ile Kara Kum'u yurt tutmuştuk.” (T1 B 7)

ötüntök ötünçümün eşidü bérti “Arz ettiklerini işitiverdi (dikkate ald1).” (T1 G8)

bo yolun yorısar yaramaçı tédim "Bu yolu kullanmak işe yaramayacak, dedim." (T1 D6)

ol yolun yorısar unç tédim "O yolu kullansak mümkün olabilir, dedim." (T1 D7)

kanın ölürtümüz "Hanlarını öldürdük.” (T1 K4)

yawgusın şadın anta ölürti “Yabgusunu, şadını orada öldürdük.” (T2 B6-7)

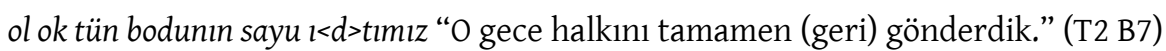




\section{J(৫)}

keligme beglerin bodunın etip yıgı "Gelen beyleri (ve) halkı düzene sokup bir araya topladım." (T2 B8)

on ok süsin sületdim "On Ok askerini (onlara karş1) sefer ettirdim.” (T2 B8)

\subsection{3. $\{+\mathrm{nI}\}$}

\subsubsection{Belirtili Nesne İşlevi}

türük begler bodun bunı éşidin “Türk beyleri (ve) halkı bunu dinleyin.” (KT G10)

on ok oglına tatına tegi bunı körü bilin "On Ok oğullarına, yabancılarına kadar bunu görüp bilin." (KT G12)

türük begler bodun bunı éşidin "Türk beyleri (ve) halkı bunu dinleyin.” (BK K8)

bunı körü bilì "Bunu görüp anlayın.” (BK K15)

yorımasar bizni "Ordu sevk etmezsek bizi” (T1 K5)

bizni ölürteçi kök témiş “Bizi öldürecektir, demiş." (T1 K6)

anı yoglatayın tédi “Onun cenaze törenini yaptırayım, dedi." (T1 K7)

tawgaçgaru kunı seyünüg ıdmış “Çin'e General Ku'yu Göndermişler.” (T1 G2)

anı ert<d>imiz "Onları geçtik." (T2 B9)

\subsection{Yönelme Durumu}

Orhun yazıtlarında yönelme eki olarak genellikle $\{+\mathrm{kA}\}$ eki, birinci ve ikinci tekil kişi iyelik ekleri almış sözcüklerde $\{+A\}$ eki, üçüncü kişi iyelik eki almış sözcüklerde $\{+n A\}$ eki kullanılır (Tekin 2016: 104). Yönelme halinde bulunan bir isim veya isim gibi işlem gören bir kelime grubu fiili yer bakımından tamamlar, hareketin yöneldiği yeri bildirir (Eraslan 2000:72).

Yönelme durumunun sentaktik yapıda yaklaşma, verme-bulunma, hedef, zaman, ilgi, tarz anlamları vardır.

\subsection{1. $\{+\mathrm{kA}\}$}

İyelik eksiz sözcüklerde kullanılan yönelme ekidir.

\subsubsection{Dolaylı Tümleç İşlevi}

taloyka kiçig tegmedim “(Büyük) Okyanusa ulaşmama az kaldı.” (KT G3)

töpötke kiçig tegmedim “Tibet'e ulaşmama az kaldı.” (KT G3) 
ney sawım <bar> erser bengü taşka urtum "Ne kadar sözüm varsa ebedi taşa kazıdım (yazdım)." (KT G11)

tawgaç bodunka beglik urı oglın kul boltı "Çin halkına, beyliğe layık oğulları köle oldu.” (KT D7) tawgaçgı begler tawgaç atın tutupan tawgaç kaganka körmiş "Çinlileri benimsemiş beyler Çin unvanlarını alarak Çin kağanına tabi olmuşlar.” (KT D7-8)

ilgerü kün tugsıkda bök<k>üli kaganka tegi süleyü bérmiş "Doğuda gün doğusundaki Bökküli (Kore) kağanına kadar sefer edivermiş." (KT D8)

kurıgaru temir kapıgka tegi süleyü bérmiş "Batıda Demir Kapı'ya kadar sefer edivermiş." (KT D8)

tawgaç kaganka élin törösin alı bérmiş “Çin kağanına ülkesini, yasalarını alıvermişler.” (KT D8 kimke élig kazganur men "Kime ülke kazanıyorum?” (KT D9)

ne kaganka işig küçüg bérür men "Hangi kağana işi gücü veriyorum?” (KT D9)

tawgaç kaganka yagı bolmış "Çin kağanına düşman olmuş." (KT D9)

kaøım kaganka başlayu baz kaganıg balbal tikmiş “Babam kağana ilk önce Baz Kağan’ı balbal (olarak) dikmişler." (KT D16)

ney yılsıg bodunka olormadım "Refah içerisindeki bir halka kağan olmadım.” (KT D26)

yaraklıgdı kaganka ançoladı "Silahlı (olduğu halde) kağana sundu." (KT D32)

yénçü ügüzüg keçe temir kapıgka tegi süledimiz “İnci (Sirderya) Irmağı'nı geçip Demir Kapı'ya kadar sefer ettik." (KT D39)

balıka basıkdı "Çamura (bataklık?) gömdü.” (KT K8)

yégirmi kün olorup bo taşka bo tamka kop yolkl>ug tégin bitidim "Yirmi gün oturup bu taşa, bu duvara tamamen (ben) Yollug Tégin yazdım." (KT G-D)

töpötke kiçig tegmedim “Tibet’e ulaşmama az kaldı.” (BK K3)

bengü taşka urtum “Ebedi taşa kazıdım (yazdım).” (BK K8)

tawgaç bodunka beglik urı oglın kul kıltı "Beyliğe layık oğullarını Çin halkına köle yaptı." (BK D7)

tawgaç kaganka körmiş "Çin kağanına tabi olmuşlar." (BK D7)

ne kaganka işig küçüg bérür men tér ermiş "Hangi kağana hizmet ediyorum? dermiş." BK D9)

ança tép tawgaç kaganka yagı bolmış "Böyle deyip Çin kağanına düşman olmuş." (BK D9)

tört yégirmi yaşımka tarduş bodun üze şad olortum "On dört yaşımda Tarduş halkına şad (olarak) atandım." (BK D15)

yışka agdı “(Ormanlı) dağlarına tırmandı.” (BK D37) 


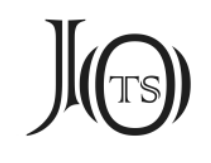

otuz artukı tört yaşıma oguz tezip tawgaçka kirti “Otuz dört yaşımda Oğuzlar kaçıp Çin'e s1ğındı." (BK D38)

tatawı bodun tawgaç kaganka körti “Tatavı halkı Çin kağanına bağlıyd.." (BK D39)

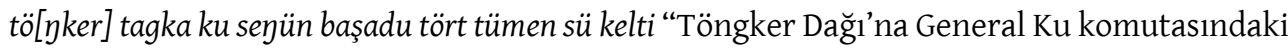
kırk bin asker geldi." (BK G7-8)

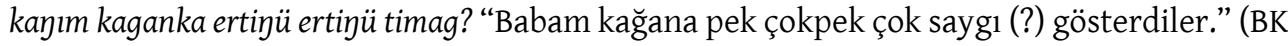
G14)

türk bodun tawgaçka körür erti “Türk halkı Çin'e tabi idi.” (T1 B1)

kanın kodup tawgaçka yana içikdi “Hanını bırakıp Çin'e yeniden tabi oldu.” (T1 B2)

ügüzke tüşdi “Irmağa döküldüler." (T1 G9)

türk kaganıg türk bodunug ötüken yérke ben özüm bilge toñukuk<kelürtüm> "Türk kağanını, Türk halkını Ötüken topraklarına bizzat ben, Bilge Toñukuk, getirdim.” (T1 G10)

şantuy balika taloy ügüzke tegmiş yok ermiş "Şandong kentine, okyanusa (?) ulaşan olmamış." (T1 D1)

şantuy balkka taloy ügüzke tegürtüm "Şandong kentine (ve) (Büyük) Okyanusa kadar ulaştırdım." (T1 D2)

ilk kırkızka sülese]r yeg ermiş tédim "ilk önce Kırgızlara sefer etsek daha iyi olacak, dedim." (T1 D6)

anı suwka b[ardımız] “Anı Irmağı'na vardık.” (T1 K3)

atıg ıka bayur ertimiz "Atları ağaçlara bağlıyorduk.” (T1 K3)

kaganka kırkız bodunı içikdi yükünti “Kırgız halkı kağana tabi oldu, boyun eğdi.” (T1 K4)

bulçuka tan üntürü tegdimiz "Bulçu'ya tanatarken ulaştık." (T1 K11)

temir kapıgka tegi ertimiz “Demir Kapı'ya kadar ulaştık.” (T2 G1)

ténsi ogl aytıgma tagka tegmiş idi yok ermiş “Tensi Oğlu denilen dağa ulaşan asla yokmuş.” (T2 G3)

éltériş kaganka türük bögü kaganka türük bilge kaganka “Elteriş Kağan’a, Türk Bögü Kağan’a, Türk Bilge Kağan'a" (T2 G6)

\subsubsection{Zarf Tümleci İşlevi}

bo ödke olortum "Bu zamanda tahta oturdum.” (KT G1)

barkın bedizin bitig taşın béçin yılka yétinç ay yéti otuzka kop alkdımız "Anıt mezarını, süslemelerini, yazıt taşını, maymun yılının yedinci ayının yirmi yedisinde tamamen bitirdik." (KT K-D)

kagım kagan it yıl onunç ay altı otuzka uça bardı "Babam (Bilge) kağan it yılının onuncu ayının yirmi altısında sonsuzluğa uçup gitti.” (BK G10) 


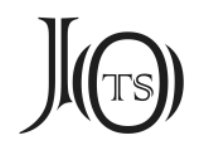

lagzın yıl beşinç ay yéti otuzka yog ertürtüm "Domuz yılının beşinci ayının yirmi yedisinde cenaze törenini yaptırdım." (BK G10)

kırkızıg uka basdımız “Kırgızları uykuda (iken) baskına uğrattık.” (T1 K3)

neke tezer biz “Ne diye kaçacağız?" (T2 B 3

üküş téyin neke korkur biz "Çok diye niye korkuyoruz?” (T2 B4)

\subsubsection{Edat Tümleci İşlevi}

ilgerü şantuy yazıka tegi süledim “Doğuda Şandong Ovası'na kadar sefer ettim.” (KT G3)

bérgerü tokuz ersinke tegi süledim “Güneyde Dokuz Ersin'e kadar sefer ettim.” (KT G3)

temir kapıgka tegi süledim “Demir Kapı'ya kadar sefer ettim.” (KT G4)

bunça yérke tegi yorıtdım "Bunca yere kadar asker sevk ettim." (KT G4)

ilgerü kadırkan yışka tegi kerü temir kapıgka tegi konturmış "Doğuda Kadırkan (ormanlı) Dağları'na kadar, batıda Demir Kapı'ya kadar yerleştirmiş.” (KT D2)

éçim kagan birle ilgerü yaşıl ügüz şantun yazıka tegi süledimiz "Amcam kağan ile doğuda Sarı Irmak'a (ve) Şandong Ovası'na kadar sefer ettik.” (KT D17)

kurıgaru temir kapıgka tegi süledimiz “Batıda Demir Kapı'ya kadar sefer ettik.” (KT D17)

kurıgaru kejü tarmanka tegi türük bodunug ança konturtumuz ança etdimiz "Batıda Kengü Tarman’a kadar Türk halkını öylece yerleștirdik, öylece düzenledik.” (KT D21)

ersinke tegi süledim “Ersin'e kadar sefer ettim.” (BK K3)

temir kapıgka tegi süledim “Demir Kapı'ya kadar sefer ettim.” (BK K3)

ilgerü kadırkan yışka tegi “Doğuda Kadırkan (ormanlı) Dağları'na kadar” (BK D3)

temir kapıgka tegi konturmış “Demir Kapi'ya kadar yerleştirmiş.” (BK D4)

ilgerü kün tugsıka bök<k>üli kaganka tegi süleyü bérmiş "Doğuda gün doğusundaki Bökküli (Kore?) kağanına kadar sefer edivermiş." (BK D8)

kurıgaru temir kapıgka <tegi> süleyü bérmiş "Batıda Demir Kapı'ya kadar sefer edivermiş." (BK D8)

ilgerü yaşl ügüz şantun yazıka tegi süledimiz “Doğuda Sarı Irmak (ve) Şandong Ovası'na kadar sefer ettik." (BK D15)

kurıgaru temir kapıgka tegi süledimiz “Batıda Demir Kapı'ya kadar sefer ettik.” (BK D15)

keĐü tarwanka tegi türük bodunug ança konturtumuz ança étdimiz "Kengü Tarvan'a kadar Türk halkını öylece yerleştirdik, öylece düzenledik.” (BK D18)

bir otuz yaşııa çaça senünke süyüşdümüz "Yirmi bir yaşında iken general Çaça'yla savaştık." (KT D32)

tawgaçka yéti yégirmi süyüşdi “Çinlilerle on yedi kez savaştı.” (T2 G5) 


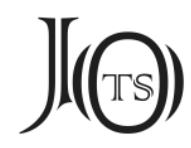

kıtañka yéti sünüşdi “Kitanlılarla yedi kez savaştı.” (T2 G5)

oguzka béş sünüşdi “Oğuzlarla beş kez savaştı.” (T2 G5)

\subsection{2. $\{+y A\}$}

\section{Üçüncü kişi iyelik eki almış sözcüklerde kullanılmıştır.}

\subsubsection{Dolaylı Tümleç İşlevi}

yırgaru yér bayırku yériye tegi süledim "Kuzeyde Yer Bayırku topraklarına kadar sefer ettim." (KT G4)

bir kişi yapılsar uguşı bodunı böşükine tegi kıdmaz ermiş "Bir kişi yanıldığında soyu sopu, halkı (ve) akrabalarına varıncaya kadar sağ bırakmazmış.” (KT G6)

süçig sawina yımşak agısıı a arturup üküş türük bodun öltüg "Tatlı sözüne, yumuşak ipeğine kanıp Türk halkından birçoğunuz öldü.” (KT G6)

on ok oglıya tatına tegi bunı körü bilin "Ok oğullarına, yabancılarına kadar bunu görüp bilin." (KT G12)

kırkız yérige tegi süledimiz “Kırgız yurduna kadar sefer ettik.” (KT D17)

bizine yapılkt>okın üçün kaganı ölti “Bize (karşı) yanıldığı için kağanı öldü.” (KT D19)

ilgerü kün tugsika bérgerü kün ortosinaru kurıgaru kün batsıkıøa yırgaru tün ortosinaru anta içreki bodun ko[p] m[ap]a kör[ür] "Doğuda gün doğusuna, güneyde gün ortasına, batıda gün bat1sına, kuzeyde gece ortasına kadar, oradaki tabi halklar bana bağlıdır.” (KT G2)

igidmiş bilge kaganı̇ın ermiş barmış edgü élige kentü yayıltıg "(Seni) beslemiş bilge kağanına, her tarafa ulaşmış iyi (durumdaki) yurduna (karşı) sen kendin hata ettin (ve) nifak soktun." (KT D23)

kop maya körti “Hepsi bana tabiydi." (KT D30)

umay teg ögüm katun kutına inim köl tégin er at bultı "Umay gibi annem hatunun talihi sayesinde kardeşim Köl Tégin erlik adını buldu.” (KT D31)

alp er bizine tegmiş erti "Kahraman askerler bize saldırmıştı." (KT D40)

yazııa oguzgaru sü taşıkdımız “ilkbaharda Oğuzlara doğru asker gönderdik.” (KT K8)

anta içreki bodun kop mana körür "Orada bulunan tabi halklar tamamen bana bağlıdır." (BK K2)

yırgaru yér bayırku yérine tegi sül[edim] "Kuzeyde Yer Bayırku topraklarına kadar sefer ettim." (BK K3)

ewige kirteçi sen "Obana gideceksin." (BK K14)

on ok oglina tatına tegi bunı körü bilig "On Ok oğullarına (ve) yabancılarına kadar bunu görüp anlayın." (BK K15) 


\section{$J(\Theta)$}

kögmen aşa kırkız yérine tegi sü[ledimiz “Kögmen'i aşarak Kırgızların topraklarına kadar sefer ettik." (BK D15)

bizine yayıltokın yazıntokın üçün kaganı ölti "Anlayışsızlığı için, bize (karşı) hata ettiği için kağanı öldü.” (BK D16)

ödine küni tegdök üçün yagı boltı "Gönüllerine hasetlik girdiği için düşman oldular.” (BK D2930)

bo yérde mana kul boltı "Bu yerde bana köle oldu." (BK D36)

ben özüm tawgaç eline kılıntım "Ben kendim Çin ülkesinde doğdum." (T1 B1)

türük bilge kagan éline bititdim “Türk Bilge Kağan ülkesinde tamamladım.” (T2 D8)

\subsubsection{Zarf Tümleci İşlevi}

altı yégirmi yaşııa éçim kagan elin törösin ança kazgantı "On altı yaşında, amcam kağan yurdunu, yasalarını öylece elde etti." (KT D31)

bir otuz yaşııa çaça senünke sünüşdümüz "(Köl Tégin) yirmi bir yaşında iken general Çaça’yla savaştık." (KT D32)

\subsection{3. $\{+\mathrm{A}\}$}

Birinci ve ikinci tekil kişi iyelik ekleri almış ve yer-yön bildiren sözcüklerden sonra kullanılmıştır.

\subsubsection{Dolaylı Tümleç İşlevi}

kişi oglınta üze eçüm apam bumın kagan istemi kagan olormış “Insanoğlunun üzerinde atalarım, dedelerim Bumın Kağan (ve) İstemi Kağan tahta oturmuş." (KT D1)

üze türük tegrisi “Yukarıda Türk (ebedi) göğü” (KT D10)

berye tawgaç bodun yagı ermiş "Güneyde Çin halkı düşmanmış." (KT D12-14)

yırya baz kagan tokuz oguz bodun yagı ermiş "Kuzeyde Baz Kağan (liderliğindeki) Dokuz Oğuz halkı düşmanmış." (KT D12-14)

özüm tarduş bodun üze şad ertim "Kendim Tarduş halkının başında şaddım.” (KT D17)

üze tegri basmasar "Yukarıda gök çökmezse" (KT D22)

içre aşsız taşra tonsuz yawız yawlak bodunta üze olortum "Karnı aç, sırtı açıkta olan, kötü durumda (ve) perişan bir halka kağan oldum.” (KT D26)

yırgaru oguz bodun tapa ilgerü kıtañ tatawı bodun tapa bérgerü tawgaç tapa ulug sü éki yégir[mi süledim] "Kuzeyde Oğuz halkı tarafına, doğuda Kitan (ve) Tatavı halkı tarafına, güneyde Çin tarafına büyük ordu (ile) on iki sefer ettim.” (KT D23-28)

kızın ertiyü ulug törön ogluma alı bértim "Kızını pek büyük törenle oğluma alıverdim." (BK K10) 


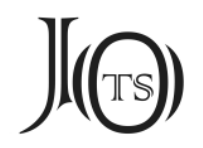

üze tenri asra yér yarllkadok üç̧ün] "Yukarıda (ebedi) gök, aşağıda yer lütfettiği için” (BK K10) türüküme bodunuma kazganu bértim eti bértim "Türklere (tabi) halkım için kazandım, elde ettim." (BK K12)

tört yégirmi yaşımka tarduş bodun üze şad olortum "On dört yaşımda Tarduş halkına şad (olarak) atandım." (BK D15)

üze tegri basmasar "Üstte gök çökmezse” (BK D18)

yawız yawlak bodunta [üze olortum "Beslemiş kağanına, her tarafa ulaşmışiyi (durumdaki) yurduna (karşı) sen kendin hata ettin (ve) nifak soktun.” (BK D21)

kop mana körti “Tamamı bana tabi oldu." (BK D24)

yéti yégirmi yaşıma tanut tapa süledim "On yedi yaşımda Tangutlar tarafına sefer ettim." (BK D24)

sekiz yégirmi yaşıma altı çuw [sogdak] tapa süledim "On sekiz yaşımda Altı Çuv Soğdak tarafına sefer ettim." (BK D24-25)

[b]érye tawgaçda atı küsi yok boltı "Güneyde Çin topraklarında adı, sanı yok olup gitti." (BK D36)

türüküme bodunuma yegin ama kazganu bértim "Türklerim, halkım için daha iyisini öylece elde ettim." (BK G10)

bérye tawgaçıg öyre kıtañıg yırya oguzug üküş ök ölürti "Güneyde Çinlileri, doğuda Kitanlıları, kuzeyde Oğuzları çokça mahvetti." (T1 B7)

anta ötrö kaganıma ötüntüm “Ondan sonra kağanıma arz ettim.” (T1 G5)

kaganıma ötünüp sületdim “Kağanıma arz edip sefer ettirdim.” (T1 D1)

ol üç kagan ögleşip altun yış üze kawışalım témiş "O üç kağan anlaşıp "Altay (ormanlı) Dağları'nda birleşelim, demiş." (T1 D3)

bilge toñukuka bana aydı "Bilge Toñukuk'a (yani) bana söyledi." (T1 K7)

ben saya ne ayayin tédi “Ben sana (daha) ne diyeyim, dedi." (T1 K8)

\subsubsection{Zarf Tümleci İşlevi}

éki otuz yaşıma tawgaç tapa süledim "Yirmi iki yaşımda Çin tarafına sefer ettim." (BK D25-26) altı otuz yaşıma çik bodun kırkız birle yagı boltı "Yirmi altı yaşımda Çik halkı Kırgızlarla düşman oldu." (BK D26)

yéti o[tuz yaşı]ma kırkız tapa süledim "Yirmi yedi yaşımda Kırgızlara doğru sefer ettim." (BK D26)

otuz yaşıma béş balk tapa süledim “Otuz yaşımda Beşbalık’a doğru sefer ettim.” (BK D28)

otuz artukı bir yaşıma karlok badun bunsuz erür barur "Otuz bir yaşımda Karluk halkı sıkıntısizca hareket eder hale geldi" (BK D28-29) 


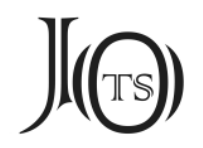

otuz artukı tört yaşıma oguz tezip tawgaçka kirti "Otuz dört yaşımda Oğuzlar kaçıp Çin'e s1ğınd." (BK D38)

otuz artukı sekiz yaşıma kışın kıtañ tapa süledim "Otuz sekiz yaşımda kışın Kitan tarafına sefer ettim." (BK G2)

elig yaşıma tatawı bodun kıtañda adr[ltı] "Elli yaşımdayken Tatavı halkı Kitanlılardan ayrıldı." (BK G7)

\subsection{Bulunma Durumu}

Orhun yazıtlarında $\{+\mathrm{d} A\}$ eki hem bulunma hem de ayrılma durumu için kullanılmıştır. Eski Türkçede uzaklaşma ifadesi için $\{+\mathrm{dA}\}$ ve $\{+\mathrm{tA}\}$ kullanılmıştır. Fakat bu ablatif eki olmayıp lokatif ekinin ablatif fonksiyonu için kullanılmasından başka bir şey değildir (Ergin 2009: 236). Bulunma durumu, sentaktik yapıda yer, zaman, vasıta, devamlılık, müddet, tarz, karşılaştırma işlevleriyle dolaylı tümleç ve zarf tümleci görevlerinde kullanılmıștır.

\subsubsection{Dolaylı Tümleç İşlevi}

Mekân ifadeleriyle birlikte kullanılarak sentaktik yapıda dolaylı tümleç işlevi yapar:

tẹri teg teyride bolmış türük bilge kagan “(Ben) Tengriteg Tengride Bolmış Türk Bilge Kağan('1m)." (KT G1)

türük kagan ötüken yış olorsar élte buy yok “Türk kağanı Ötüken (ormanlı) Dağları'nda oturursa ülkede sıkıntı olmaz." (KT G3)

bo yérde olorup tawgaç bodun birle tüzültüm "Bu yerde oturarak Çin halkı ile (ilişkileri) düzelttim." (KT G4)

yagru kontokda késre anta öyür ermiş "Yakına yerleştikten sonra kötülükleri orada düşünürlermiş." (KT G5)

anta añıg kişi ança boşgurur ermiş “Orada kötü (düşünceli) kişiler şöyle akıl verirmiş.” (KT G7) kop anta alkıntıg arıltıg "Oralarda tamamen yok oldun, tükendin.” (KT G9)

azu bo sawımda igid bar gu "Hiç bu sözümde yalan var mı?” (KT G10)

yayılıp ölsikinin bunta urtum "Yanılıp öleceğinizi de buraya kazıdım (yazdım)." (KT G10-11) erig yérte erser ança erig yérte beygü taş tokıtdım bitidim "Ulaşılabilir yerde ise, böylesi ulaşılabilir yerde ebedi taş kazıttım, yazdırdım.” (KT G13)

kayım élteriş kaganıg ögüm élbilge katunug teyri töpösinte tutup yügerü kötürmiş "Babam Elteriş Kağan'1, annem Elbilge Hatun'u (ebedi) gök, tepelerinden (?) tutup (göğe) yükseltmiş” (KT D11) 


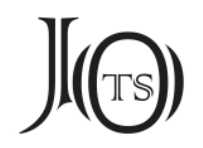

tölis tarduş bodunug anta etmiş “Tölis (ve) Tarduş halklarını orada örgütlemiş.” (KT D13)

kagan at bunta biz bértimiz "Kağan unvanını burada biz verdik." (KT D20)

bardok yérde edgüg ol erinç “Gittiğiniz yerlerde elde ettiğiniz şu kuşkusuz.” (KT D24)

ıdok başda sünüşdümüz “Idok Baş’ta savaştık.” (KT D31)

ol süg anta yok kışdımız "O orduyu orada yok ettik." (KT D32)

ol at anta ölti "O at orada öldü." (KT D33)

ol süg anta yok kışdımız "O orduyu orada yok ettik." (KT D34)

anı yañip türgi yargun költe buzdumuz “Onun ordusunu dağıtıp Türgi Yargun Gölü’nde bozguna uğrattık." (KT D34)

kaganın birle sona yışda sü̈üşdümüz "Kağanı ile Songa (ormanlı) Dağları’nda savaştık." (KT D35)

türgéş kagan süsi bulçuda otça borça kelti “Türgeş kağanının ordusu Bulçu'da ateş gibi kor gibi (üzerimize) geldi." (KT D37)

kaganın anta ölürtümüz élin altımız “Kağanını orada öldürdük.” (KT D38)

kara türgéş bodunug anta ölürmiş almış "Kara Türgeş halkını orada öldürmüş, ele geçirmiş." (KT D40)

tamag ıdok başda süyüşdümüz “Tamag Idok Baş'ta savaştık.” (KT K1)

tégin ol süyüşde otuz yaşayur erti "Köl Tégin o savaşta otuz yaşındayd." (KT K2)

kara költe süyüşdümüz “Kara Göl'de savaştık.” (KT K2)

az bodun anta yok boltt "Az halkı orada yok oldu." (KT K3)

ey ilk[i] togu balkda sünüşdümüz “ilk önce Doğu Balık’ta savaştık.” (KT K4)

ékinti koşulgakda ediz birle sünüşdümüz “ikinci olarak Koşulgak’ta Edizlerle savaştık.” (KT K5)

ediz bodun anta ölti "Edizhalkı orada yok oldu." (KT K6)

törtünç çuş başınta sünüşdümüz “Dördüncü olarak Çuş Başı'nda savaştık.” (KT K6)

beşinç ezgenti kadızda oguz birle sünüşdümüz “Beşinci olarak Ezgenti Kadız'da Oğuzlarla savaştık." (KT K7)

togra bir uguş alpagu on erig tona tégin yoginta egirip ölürtümüz "Tongralardan bir grup kahraman (ile) on askeri Tonga Tégin'in cenaze töreninde çevirip öldürdük.” (KT K7)

ol sü anta ölti “O ordu orada yok oldu." (KT K8)

ölügi yurtda yolta yatu kaltaçı ertigiz “ölüsü de orada burada kala kalacaktınız.” (KT K9)

anta içreki bodun kop mana körür "Orada bulunan tabi halklar tamamen bana bağlıdır." (BK K2) 
kayım éltériş kaganıg ögüm élbilge katunug tegri töpösinte tutup yügerü kötürti "Babam Elteriş Kağan'ı annem Elbilge Hatun'u (ebedi) gök, tepelerinden tutup (göğe) yükseltmiş” (BK D10) kagan atıg bunta biz bértimiz "Kağan unvanını burada biz verdik." (BK D17)

bodunug anta buzdum "Halkını orada bozguna uğrattım." (BK D25)

ıdok başda sünüşdüm “Idok Baş'ta savaştım.” (BK D25)

kaganın birle sona yışda süyüşdüm "Kağanı ile Songa (ormanlı) Dağları'nda savaştım.” (BK D27)

bulçuda sü̈üşdümüz "Bulçu'da savaştık." (BK D28)

tamag ıdok başda süyüşdüm “Tamag Idok Baş’ta savaştım.” (BK D29)

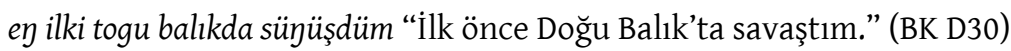

törtünç ezgenti kadızda süyüşdüm “Dördüncü olarak Ezgenti Kadız'da savaştım.” (BK D31)

ékin sü ewde erti “ikinci ordu karargâhta idi.” (BK D32)

aguda éki ulug sünüşs sünüşdüm “Agu'da iki büyük savaş yaptım.” (BK D34)

bo yérde kelti "Buraya geldi." (BK D35)

[b]érye tawgaçda atı küsi yok boltı "Güneyde Çin topraklarında adı, sanı yok olup gitti." (BK D36)

bo yérde mana kul boltı "Bu yerde bana köle oldu." (BK D36)

karagan kısltta ewin barkın anta buzdum "Karagan Geçidi'nde evini barkını orada yıktım." (BK D37)

tönker tagda tegip tokıdım üç tümen süg [ölür]tüm “Töngker Dağı'nda saldırıp otuz bin askerini öldürdüm.” (BK G8)

türk sir bodun yérinte bod kalmadı “Türk Sir halkının topraklarında boy kalmadı." (T1 B3-4) ıda taşda kalmışı kuwranıp yéti yüz boltı "Yazıda yabanda kalanlar toplanıp yedi yüz (kişi) oldular." (T1 B4)

toruk bukalı semiz bukalı ırakda böyüser (?) “Zayıf boğa ile semizboğa uzakta böğürse.” (T1 B56)

türk sir bodun yérinte idi yormazun "Türk Sir halkı (oldukları) yerde hiç hareket edemesin." (T1 G4)

yañdok yolta yeme ölti “Bozguna uğramış olanlardan yolda da ölenler öldü." (T1 G9)

yurtda yatu kalur erti “Ortalık yerde yatar hale geldiler.” (T1 D2)

altun yış̧da oloruy tédi “Altay (ormanlı) Dağları'nda oturun, dedi.” (T1 K7)

altun yışda olortumuz “Altay (ormanlı) Dağları'nda oturduk.” (T1 K8)

yarış yazıda terilelim témiş “Yarış Ovası'nda toplanalım, demişler.” (T1 K9) 


\section{$J(\Theta)$}

yarış yazıda on tümen sü térilti “Yarış Ovası'nda yüz bin (kişilik) ordu toplandı." (T2 B1)

\subsubsection{Zarf Tümleci İşlevi}

\section{Zaman ifadesiyle sentaktik yapıda zarf tümleci olarak işlev yapar:}

kagan uçdokda özüm sekiz yaşda kaltım "Kağan sonsuzluğa uçtuğunda kendim sekiz yaşındaydım." (BK D14)

[türgéş bodunug] uda basdım “Türgeş halkını uykuda (iken) baskına uğrattım.” (BK D27)

kırkız bodunug uda basdım "Kırgız halkını uykuda (iken) baskına uğrattım.” (BK D27)

amgı korgan kışladokda yut boltı "Amgı Korgan'da kışladığımızda kıtlık oldu." (BK D31)

anta késre "Ondan sonra" (KT D4, D5, D34, D39, T1 B6)

anta késre inisi kagan bolmış "Ondan sonra küçük kardeşi kağan olmuş." (BK D5)

\subsection{3. $\{+\mathrm{dA}\}$ Ekinin Ayrilma İşlevi}

Hem bulunma hem de ayrılma durumları için birlikte kullanılan $\{+\mathrm{dA}\}$ ekinin ayrılma işlevi sentaktik yapıda ortaya çıkmaktadır:

ötüken yışda yeg idi yok ermiş “Ötüken (ormanlı) Dağları'ndan daha iyisi asla yok imiş.” (KT G4)

yagru kontokda késre anıg bilig anta öyür ermiş "Yakına yerleştikten sonra kötülükleri orada düşünürlermiș." (KT G5)

tawgaç kaganta bedizçi kelürtüm "Çin kağanından süsleme ustası getirttim.” (KT G11)

yarıkınta yalmasınta yüz artuk okun urtı "Zırhından (ve) kaftanından yüzden fazla ok vurdular." (KT D33)

anta yana kirip türgéş kagan buyrukı az totokug eligin tutdı "Oradan yine girip Türgeş kağanının komutanlarını (ve) Azların askeri valisini eliyle yakaladı.” (KT D38)

közde yaş kelser tıda köyülte sıgıt kelser yanturu sakıntım katıgdı sakıntım "Gözden yaş gelse engelleyerek gönülden ağıtlar gelse (ağıtımı) bastırarak düşündüm.” (KT K11)

tawgaç kaganta işiyi likey kelti “çin kağanından İşiyi Likeng geldi.” (KT K12)

töpöt kaganta bölün kelti “Tibet kağanından Bölün geldi.” (KT K12)

bukarak uluş bodunta nek seyün ogul tarkan kelti "Buhara kentihalkından General Nek (ile) Oğul Tarkan geldi." (KT K12)

kırkız kaganta tarduş ınançu çor kelti “Kırgız kağanından Tarduş Inançu Çor geldi.” (KT K13)

on ok oglum türgéş kaganta makaraç tamgaçı oguz bilge tamgaçı kelti "On Ok evladım Türgeş kağanından mühürdar Makaraç (ile) mühürdar Oğuz Bilge geldi.” (KT K13) 


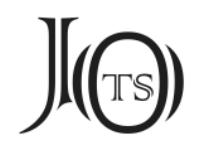

ıgar oglaniıızda taygunuyuzda yégdi igidür ertigiz "Gözde çocuklarınızdan, gençlerinizden daha iyi besliyordunuz." (KT G-D)

elig yaşıma tatawı bodun kıtañda adr[ltı] "Elli yaşımdayken Tatavı halkı Kitanlılardan ayrıldı." (BK G7)

tawgaçda adrıltı kanlantı “Çin'den ayrıldı, han sahibi oldu.” (T1 B2)

ben yirdint<a> yan tegeyin "Ben kuzey taraftan saldırayım." (T1 G4)

öyre kıtañda berye tawgaçda kurıya kordanta yırya oguzda éki üç bin sümüz keltéçimiz bar mu "Doğuda Kitan'dan, güneyde Çin'den, batıda Hoten'den, kuzeyde Oğuz'dan iki üç bin (kadar) askerimiz var." (T1 G7)

tuglada oguz kelti “Tula Irmağı (tarafından) Oğuzlar geldi." (T1 G8)

kırkızda yantımız "Kırgızlardan geri döndük.” (T1 K5)

türgeş kaganta küreg kelti “Türgeş kağanından kaçak geldi.” (T1 K5)

kant<a> yan sawlg yana kelti “Handan yanit geldi.” (T1 K9-10)

bizinte éki uçı sııarça artuk erti “iki kanadı bizim yarımızdan fazlaydı.” (T2 B5)

anta berüki "Oradan bu tarafa” (T2 G2)

\subsection{Ayrilma Durumu}

Orhun yazıtlarında genel olarak ayrılma eki işlevini $\{+\mathrm{dA}\}$ üstlenmiştir. KORKMAZ, Eski Türkçenin \{+tIn\} eki üzerindeki araştırmaların esas itibariyle ekin yapısını çözmek amacını güttüğünden ekin görevleri arasındaki birbirine geçişler ve değişmelerin incelenmediğini, bu ekin hem ayrılma eki hem de yön zarfı yapan yön gösterme eki olduğunu belirtmiştir (2011: 14).

\subsubsection{Dolaylı Tümleç İşlevi}

yaraklıg kantan kelip yaña életdi “Silahlı (düşmanlar) nereden gelip sizi dağıtabilecekti?” (KT D23)

süyüglüg kantan kelipen süre életdi "Mizraklı (düşmanlar) nereden gelip (sizi yurdunuzdan) sürebilecekti." (KT D23)

kurıdın [s]ogud örti “Batıda Soğdlular ayaklandı." (KT B)

yaraklıg kantan kelip yaña életdi “Silahlı (düşmanlar) nereden gelip sizi nasıl dağıtabilecekti?” (BK D19)

oguzduntun küreg kelti “Oğuzlardan kaçak geldi.” (T1 G1)

oguzduntun küreg kelti “Oğuzlardan kaçak geldi.” (T1 G1)

tawgaç berdin yen teg "Çinliler güney taraftan saldırın." (T1 G4) 


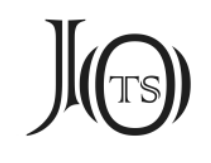

kıtañ ögdün yen teg "Kitanlılar doğu taraftan saldırın." (T1 G4)

öydün kagangaru sü yorllm témiş “Doğudaki kağana ordu sevk edelim, demiş.” (T1 K5)

\subsection{Eşitlik Durumu}

Adların eşitlik hâli $\{+c ̧ A\}$ eki ile yapılır. Kelime gruplarında ve cümlede fiilin nasıl ve ne şekilde olduğunu veya yapıldı̆̆ını, fiilin oluşunu veya yapılış tarzını ifade etmek için kullanılır (Ergin 2009: 239). Cümle içerisinde benzerlik, gibilik, eşitlik, miktar ve görelik yönünden anlam bağıntıları kurar.

\subsubsection{Zarf Tümleci İşlevi}

\section{Benzerlik ve Gibilik Yönünden}

kanıy suwça yügürti sünüküy tagça yatdı "Kanlarınız su gibi aktı, kemikleriniz dağ gibi yığıldı." (KT D24)

[ka]nı ügüzçe yügürti sügüküg tagça yatdı "Kanlarınız ırmak gibi aktı, kemikleriniz dağ gibi yı ̆̆lldı." (BK D20)

türgéş kagan süsi bulçuda otça borça kelti “Türgeş kağanının ordusu Bulçu'da ateş gibi kor gibi (üzerimize) geldi." (KT D37)

türgéş kagan süsi otça borça kelti "Türgeş kağanının ordusu ateş gibi, kor gibi (üzerimize) geldi." (BK D27)

örtçe kızıp kelti “Ateş gibi kızmış (bir halde) geldiler.” (T2 B5)

\section{Eşitlik ve Miktar Yönünden}

bunça yérke tegi yorıtdım "Bunca yere kadar asker sevk ettim." (KT G4)

süçig sawin yımşak agin arıp ırak bodunug ança yagutır ermiş "Tatlı sözle, yumuşak ipeklerle kandırıp uzaktaki halkları öylece (kendine) yaklaştırırmış.” (KT G5)

anta añıg kişi ança boşgurur ermiş "Orada kötü (düşünceli) kişiler şöyle akıl verirmiş” (KT G7) oksuz kök türük ança olorur ermiş “Dağınık haldeki Türkler öylece yaşıyorlarmış.” (KT D3) anı üçün élig ança tutmış erinç "Onun için ülkeyi öylece sahiplenmişler elbette." (KT D3) bunça bodun kelipen sıgtamış yoglamış "Bu kadar halk gelerek ağıt yakmış, yas tutmuş." (KT D4)

ança sakıntım “Öylece düşündüm.” (KT K11)

taş bark [etgüçig] bunça bedizçig toygun éltewer kel[ürti] "Taş anıt mezarı yapan bunca süsleme ustasını Toygun Eltever getirdi." (KT K-D)

kotay buysuz ança bérür “ípekli kumaşları sıkıntısızca verirler.” (BK K4) 


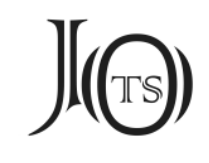

ança boşgurur ermiş “Öylece akıl verirlermiş.” (BK K5)

köglüyçe uduz tédi “(Orduyu) bildiğin gibi sevk et dedi.” (T1 G8)

bizinte éki uçı sı̄arça artuk erti “(Onların) iki kanadı bizim yarımızdan fazlaydı.” (T2 B5)

eligçe er tutdumuz "Elli kadar askerini yakaladık." (T2 B7)

azça bodun tezmiş erti “Az sayıda halk kaçmıştı.” (T2 B8)

\section{Görelik Yönünden}

bodunug eçüm apam törösinçe yaratmış boşgurmış "Halkı atalarım, dedelerim yasalarına göre örgütlemiş, öğretmiş." (KT D12-13)

kıyınıg köglüyçe ay “Cezaları da uygun gördüğün şekilde ver.” (T1 K8 )

özçe tașın tutmıș teg biz "Kendimizce dışarıyı tutmuş gibiyiz." (T1 G6)

\subsection{Yön Gösterme Durumu}

Orhun yazitlarında gösterme durumu olarak $\{+g A r U\},\{+n A r U\},\{+A r U\}$ ve $\{+r A\}$ ekleri kullanılmıştır. Bu ekler günümüzde işlevselliğini kaybetmiş, kalıplaşmış olarak taşra, üzere, içeri, dışarı gibi sözcüklerde yer almaktadır.

\subsection{1. $\{+\mathrm{gArU}\},\{+\mathrm{nArU}\},\{+\mathrm{rA}\}$}

\subsubsection{Dolaylı Tümleç İşlevi}

ilgerü şantuy yazıka tegi süledim “Doğuda Şandong Ovası'na kadar sefer ettim.” (KT G3)

bérgerü tokuz ersinke tegi süledim “Güneyde Dokuz Ersin'e kadar sefer ettim.” (KT G3)

kurıgaru yénçü ügüz “Batıda İnci Irmağı” (KT G3)

yırgaru yér bayırku yérine tegi süledim "Kuzeyde Yer Bayırku topraklarına kadar sefer ettim." (KT G4)

ol yérgerü barsar türük bodun ölteçi sen "O yerlere gidersen Türk halkı öleceksin.” (KT G8) ilgerü kadırkan yışka tegi kerü temir kapıgka tegi konturmış "Doğuda Kadırkan (ormanlı) Dağları'na kadar, batıda Demir Kapı'ya kadar yerleştirmiş.” (KT D2)

kurıgaru temir kapıgka tegi süleyü bérmiş “Batıda Demir Kapı'ya kadar sefer edivermiş." (KT D8)

ilgerü kün tugsıkda bök<k>üli kaganka tegi süleyü bérmiş "Doğuda gün doğusundaki Bökküli (Kore) kağanına kadar sefer edivermiş." (KT D8)

kayım élteriş kaganıg ögüm élbilge katunug tẹri töpösinte tutup yügerü kötürmiş "Babam Elteriş Kağan'1, annem Elbilge Hatun'u (ebedi) gök, tepelerinden (?) tutup (göğe) yükseltmiş.” (KT D11) 


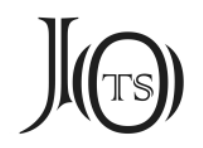

ilgerü kurıgaru sülep té[r]miş? "Doğuya (ve) batıya sefer edip (adam) derleyip, toplamış." (KT D12)

kurıgaru temir kapıgka tegi süledimiz “Batıda Demir Kapı'ya kadar sefer ettik.” (KT D17)

ilgerü kadırkan yışıg aşa bodunug ança konturtumuz "Doğuda Kadırkan (ormanlı) Dağları'nı aşarak halkı öylece yerleştirdik." (KT D21)

kurıgaru kegü tarmanka tegi türük bodunug ança konturtumuz ança etdimiz "Batıda Kengü Tarman’a kadar Türk halkını öylece yerleştirdik, öylece düzenledik.” (KT D21)

kurıgaru barıgma bardıg "Batıya gidenleriniz gitti." (KT D24)

yırgaru oguz bodun tapa ilgerü kıtañ tatawı bodun tapa bérgerü tawgaç tapa ulug sü éki yégir[mi süledim] "Kuzeyde Oğuz halkı tarafına, doğuda Kitan (ve) Tatavı halkı tarafına, güneyde Çin tarafına büyük ordu (ile) on iki sefer ettim." (KT D28)

kurıgaru yençü ügüz keçe temir kapıgka tegi süledim "Batıda İnci Irmağı (Sirderya)'nı geçip Demir Kapı'ya kadar sefer ettim." (BK K3)

türük begler bod[un ö]girip sewinip tonıtmış közi yügerü körti “Türk beyleri (ve) halkı kıvanıp sevinip yerebakan gözlerini yukarı kaldırdı." (BK D2)

ilgerü kün tugsıka bök<k>üli kaganka tegi süleyü bérmiş "Doğuda gün doğusundaki Bökküli (Kore?) kağanına kadar sefer edivermiş." (BK D8)

kurıgaru temir kapıgka <tegi> süleyü bérmiş "Batıda Demir Kapı'ya kadar sefer edivermiş." (BK D8)

kayım éltériş kaganıg ögüm élbilge katunug tegri töpösinte tutup yügerü kötürti "Babam Elteriş Kağan'ı annem Elbilge Hatun'u (ebedi) gök, tepelerinden tutup (göğe) yükseltmiș.” (BK D10) ilgerü kurıgaru sülep térmiş kuwratmış "Doğuya, batıya sefer edip (adam) derleyip toplamış." (BK D11)

ilgerü yaşll ügüz şantun yazıka tegi süledimiz “Doğuda Sarı Irmak (ve) Şandong Ovası'na kadar sefer ettik." (BK D15)

kurıgaru temir kapıgka tegi süledimiz “Batıda Demir Kapı'ya kadar sefer ettik.” (BK D15)

tokuz oguz bodun yérin suwın ıdıp tawgaçgaru bardı "Dokuz Oğuz halkı topraklarını bırakıp Çin'e gitti." (BK D35)

tawgaçgaru kunı seyünüg ıdmıı̧ “Çin’e General Ku’yu göndermişler.” (T1 G2)

kıtañgaru togra eşimig ıdmış “Kitanlılara Tongra Eşim’i göndermişler.” (T1 G2)

ögre türk kagangaru sülelim “Doğudaki Türk kağanına sefer edelim.” (T1 D3)

yokaru at yete yadagın ıgaç tutunu agturtum "Yukarı (çıarken) atları yedeğe alıp ağaçlara tutunarak çıkardım." (T1 K1)

öydün kagangaru sü yorllm “Doğudaki kağana ordu sevk edelim.” (T1 K5)

kaganım ben ewgerü tüşeyin "Ben karargâha gideyim." (T1 K6) 


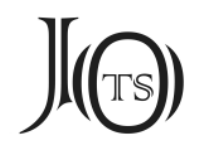

apa tarkangaru içre saw ıdmış “Apa Tarkan'a gizli haber göndermiş.” (T1 K10)

yérinerü suwinaru kontı “Topraklarına yerleşti.” (BK D40)

üze kök teyri asra yagızyér kılıntokda ékin ara kişioglı kılınmış "Yukarıda mavi gök, aşağıda yağız yer yaratıldığında ikisinin arasında insanoğlu yaratılmış.” (KT D1)

ögre kün tugsılkda bök<k>üli çöl<l>üg él "Doğuda gün doğusundaki Bökküli (Kore) bozkırı" (KT D4-5)

üze tẹri basmasar asra yér telinmeser türük bodun élinin töröyün kim artatı "Yukarıda gök çökmezse, aşağıda yer delinmezse Türk halkı! Yurdunu (ve) yasalarını kim bozabilirdi?” (KT D22)

içre aşsız taşra tonsuz yawız yawlak bodunta üze olortum "Karnı aç, sırtı açıkta olan, kötü durumda (ve) perişan bir halka kağan oldum.” (KT D21-26)

üze tegri asra yér yarlkkadok üç̧ün] "Yukarıda (ebedi) gök, aşağıda yer lütfettiği için.” (BK K10) öyre tölis begler "Doğuda Tölis beyleri” (BK G13)

ögre kıtañıg yırya oguzug üküş ök ölürti "Doğuda Kitanlıları, kuzeyde Oğuzları çokça mahvetti." (T1 B7)

apa tarkangaru içre saw ıdmıls “Apa Tarkan'a gizli haber göndermiş.” (T1 K10)

\subsubsection{Edat Tümleci İșlevi}

yazına oguzgaru sü taşıkdımız “ïlkbaharda Oğuzlara doğru asker gönderdik.” (KT K8)

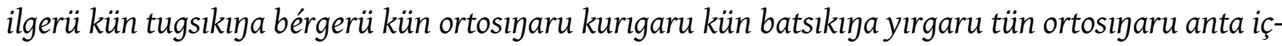
reki bodun kop maja körür "Doğuda gün doğusuna, güneyde gün ortasına, batıda gün bat1sına, kuzeyde gece ortasına kadar orada bulunan tabi halklar tamamen bana bağlıdır." (BK D1-2)

ötüken yışgaru uduztum “Ötüken (ormanlı) Dağları'na doğru sevk ettim.” (T1 G8)

bérgerü kün ortosinaru kurıgaru kün batsikına yırgaru tün ortosinaru anta içreki bodun "Güneyde gün ortasına, batıda gün batısına, kuzeyde gece ortasına kadar orada bulunan tabi halklar." (BK K2)

aparu sülemeser "Ona karşı sefer etmezsek." (T1 D3)

bög<ü> kagan bajaru ança ay ıdmış "Bögü Kağan benim içinse şöyle söylemiş." (T1 K10)

\subsection{Araç Durumu}

Adların araç durumu \{+(X)n\} eki ile kurulur (Tekin 2016:110). Kelimeler arasinda vasita ve beraberlik münasebeti kurar (Korkmaz 2011: 18). \{+n\} eki ile kurulan araç durumu Orhun yazıtlarında işlek olarak kullanılmıştır. Fakat Batı Türkçesine geçince işlekliğini kaybetmiş ve sayılı misallerde klişeleşmiş olarak 


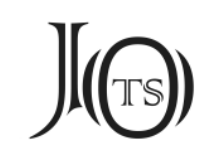

kalmış, cansız bir yapım eki haline gelmiştir (Ergin 2009: 237). Yazıtlarda vasıta durumu için $\{+n\}$ eki yanında aynı işlevde birle edatı da kullanılmıştır.

\subsubsection{Edat Tümleci İşlevi Vasita-Araç Anlamı}

süçig sawın yımşak agın arıp ırak bodunug ança yagutır ermiş "Tatlı sözle, yumuşak ipeklerle kandırıp uzaktaki halkları öylece (kendine) yaklaştırırmış." (KT G5)

on totok yurçın yaraklıg eligin tutdı “Ong Totok'un kaynını, silahlı (olduğu halde) eliyle yakaladı" (KT D32)

yarıkınta yalmasınta yüz artuk okun urtı "Zırhından (ve) kaftanından yüzden fazla ok vurdular." (KT D33)

bir erig okın urtı "Bir askeri okuyla vurdu." (KT D36)

[usı]n süyügün açdımız "Uykusunu süngülerle açtık.” (T1 K4)

\section{Birliktelik Anlamı}

kayım kagan yéti yégirmi erin taşıkmış "Babam kağan on yedi adamıyla isyan etmiş." (KT D11) ulug érkin azkıña erin tezip bardı “Ulug Erkin azıcık adamıyla kaçıp gitti.” (KT D34) köl téginig az erin értürü $l<d>$ tımız “Köl Tégin’i az (sayıda) askerle gönderdik.” (KT D40) kayım kagan yéti yégirmi erin taşıkm[ış] "Babam kağan on yedi adamıyla isyan etmiş." (BK D10)

kaganımın sületdimiz "Kağanımla sefer ettik." (T2 D3)

\subsubsection{Zarf Tümleci İşlevi}

\section{Durum Anlamı}

yadagin yalayın yana kelti “Yaya (ve) yalın (bir halde) dönüp geldiler.” (KT D28)

köl tégin yadagin oplayu tegdi “Köl Tégin yaya olarak ileri atıldı.” (KT D32)

kızın ertiqü ulug törön ogluma alı bértim "Kızını pek büyük törenle oğluma alıverdim." (BK $\mathrm{K} 10)$

\section{Zaman Anlamı}

yayın süledim "Yazın sefer ettim." (BK D39)

yazın tatawı tapa sü[ledim] “ilkbaharda Tatavı tarafa sefer ettim.” (BK G2) 


\section{$J(\Theta)$}

\section{9. İlgi Durumu}

İlgi (tamlayan) durumu belirtili ad tamlamasında adı ada veya ad soylu sözcüklere bağlayarak aitlik bildirir. Bu yönünüyle diğer durum eklerinden ayrılır. Yazıtlarda $\{+(\mathrm{n}) \mathrm{In}\},\{+(\mathrm{I}) \mathrm{n}\},\{+\mathrm{nI}\},\{+(\mathrm{I}) g\}$ ekleri ilgi durum eki olarak kullanılmıştır. Ayrıca $\{+d A\}$ üze yapısı da ilgi durumu fonksiyonunda kullanılmıştır.

\subsection{1. $\{+(n) I \eta n\}$}

Ünsüzle biten gövdelerde $\{+I y\}$, ünlüyle bitenlerde ise $\{+n I \eta\}$ biçimindedir (Tekin 2016: 101). Bu şekil, zamirler üzerinde bir ek yığılmasıyla nazallaşarak ortaya çıkmış olmalı (Özdemir 2019:162).

meniy sawımın sımadı "Benim sözümü kırmadı.” (KT G11)

türük bodunıy élin törösin tuta bérmiş éti bérmiş “Türk halkının ülkesini (ve) yasalarını tutuvermiş, düzenleyivermişler." (KT D1= BK D3)

igidmiş bilge kaganı̇ın ermiş barmış edgü éline kentü yayıltıg "Beslemiş bilge kağanının her tarafa ulaşmış iyi (durumdaki) yurduna (karşı) sen kendin hata ettin.” (KT D23)

üçünç yégen silig begin kedimlig torug at binip tegdi. "Üçüncü olarak Yegen Silig beyin zırhlı doru atına binerek saldırdı." (KT D33)

biziy sü atı toruk azukı yok erti. "Bizim ordumuzun atları zayıf, yiyecekleri (ise) yoktu." (KT D39)

bayırkunuy ak adgırıg udlıkın sıyu urtı. "Bayırku'nun ak aygırını uyluğundan vurup kırdılar." (KT D36)

bizin sü atı toruk azukı yok erti "Bizim ordumuzun atları zayıf, yiyecekleri (ise) yoktu." (KT D39)

olorupan türük bodunıy élin törösin tuta bérmiş eti bérmiş “Tahta oturup Türk halkının ülkesini (ve) yasalarını tutuvermiş, düzenleyivermiş." (BK D3)

to[kuz ogu]z meniy badunum erti “Dokuz Oğuzlar halkımdı.” (BK D29)

beniy bodunum anta erür témiş "Benim halkım orada, demiş." (T1 D4)

\subsection{2. $\{+(\mathrm{I}) \mathrm{n}\}$}

igidmiş kaganııın sawın almatın yér sayu bardıg “(seni) beslemiş kağanının sözlerini (dikkate) almadan her yere gittin." (KT G9 = BK K6)

igidmiş bilge kaganı̇ın ermiş barmış edgü éline kentü yayıltıg "(seni) beslemiş bilge kağanına, her tarafa ulaşmış iyi (durumdaki) yurduna (karşı) sen kendin hata ettin.” (KT D23)

ékin ara idi oksuz kök türük eti ança olorur ermiş “íkisinin arasındaki (bölgede) pek dağınık haldeki Türkler öylece yaşıyorlarmış." (KT D2 = BK D4) 


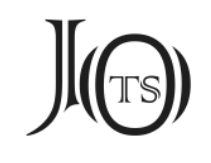

antagııın üçün "Öyle olduğun için” (KT G8-9 = BK K6)

\subsection{3. $\{+\mathrm{nI}\}$}

ÖZDEMiR, bu ekin ilgi eki olup olmama meselesinin tartışmalı olduğunu, Çağatay Türkçesinin bu şekilleri eskicil birer özellik olarak koruduğunu belirtmiştir (2019: 159).

anı üçün "onun için” (KT D3 = BK D4, D28)

\subsection{4. $\{+(\mathrm{I}) \mathrm{g}\}$}

\{+(I)g\} ilgi durum ekine kaynaklarda tek örnek verilmiştir (Özdemir 2019: 161, Tekin 2016: 101)

türük bodunug atı küsi yok bolmazun téyin “Türk halkının adı, sanı yok olmasın diye” (KT D25

$=$ BK D20, D21)

Genelde belirtme durumu olarak değerlendirilen altun yışıg, ertiş ügüzi sözcüklerindeki \{+(I)g\} eki, E. AYDIN tarafından ilgi durumu olarak ifade edilmiştir (2017a: 113).

altun yışıg yolsızın aşdım<ız> "Altay (ormanlı) Dağları'nın yolu olmayan yerlerini aştık." (T1 K11)

ertiş ügüzüg keçigsizin keçdimiz “İrtiş Irmağı'nın geçilemeyecek yerlerini geçtik.” (T1 K11)

\subsection{5. $\{+\mathrm{dA}\}$ üze}

$\{+d A\}$ eki bir isim üzerine eklenerek ardından gelen 'üzerine, üstüne’ manasındaki üze edatı ve olur-fiiliyle birlikte ilgi hâli alt fonksiyonunu karşılamaktadır (Aydin 2017b: 6).

kişi oglınta üze eçüm apam bumın kagan istemi kagan olormış "İnsanoğlunun üzerinde atalarım, dedelerim Bumın Kağan (ve) İstemi Kağan tahta oturmuş.” (KT D1 = BK D3)

\section{Sonuç}

Durum ekleri morfolojik yönden tespit edilir ve sentaktik yönden işlevleri belirlenir. Durum ekleriyle ilgili gramer çalışmalarında morfolojik incelemeler sentaktik işlevin önüne geçtiği için tanımlamalarda terim birliğine varılamamıştır. Bu çalışmada terim sorunlarına girilmemiş, sadece Türkçenin ilk yazılı kay- 


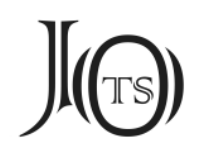

naklarından olan Orhun yazıtlarındaki durum ekleri tespit edilerek sentaktik işlevleri belirlenmiştir. İnceleme sonucunda, yazttlarda ek nöbetleşmesinin sıklıkla yaşandığı, eklerin kullanımında işlevsel genişliğin olduğu tespit edilmiştir.

Yalın durumu, sadece özne işlevinde kullanılmıştır.

Belirtme durumu, iyelik eksiz gövdelerde $\{+(\mathrm{X}) g\}$, iyelik ekli gövdelerde $\{+(\mathrm{I}) \mathrm{n}\}$ biçiminde kullanılarak belirtili nesne işlevinde kullanılmıştır. Sentaktik yapıda tizligig ve başlıııg sözcüklerindeki $\{+(\mathrm{X}) g\}$ belirtme ekinin yönelme anlamıyla kullanıldığı görülmüştür.

Yönelme eki olarak iyelik eksiz sözcüklerden sonra $\{+k A\}$ eki kullanılmıştır. Sentaktik yapıda dolaylı tümleç, zarf tümleci ve edat tümleci işlevi görmüştür. $\{+y A\}$ yönelme eki III. kişi iyelik ekinden sonra kullanılarak dolaylı tümleç ve zarf tümleci işlevinde kullanılmıştır. \{+A\} yönelme eki, birinci ve ikinci tekil kişi iyelik ekleri almış ve yer-yön bildiren sözcüklerden sonra kullanılarak dolaylı tümleç veya zarf tümleci işlevi görmüştür.

$\{+\mathrm{dA}\}$ eki, bulunma ve ayrılma anlamlarında nöbetleşe kullanılarak sentaktik yapıda dolaylı tümleç ve zarf tümleci işlevinde kullanılmıştır.

Yazıtlarda yön gösterme ekleri işlek olarak kullanılmış ve sentaktik yapıda dolaylı tümleç, edat tümleci işlevleri görmüştür. Yazıtlarda işlek olarak kullanılan yön gösterme ekleri çağdaş dönemde fonksiyonunu yitirmiş ve kalıplaşmıştir.

Eşitlik eki \{+çA\} benzerlik, gibilik, eşitlik, miktar ve görelik anlamlarıyla cümlede zarf tümleci işlevi görmüştür.

Araç durumu $\{+(\mathrm{X}) \mathrm{n}\}$ birliktelik, vasıta anlamlarıyla edat tümleci; durum, zaman anlamlarıyla zarf tümleci işlevinde kullanılmıştır. Yazıtlarda bu ekle birlikte birle edatı da kullanılmıştır. Günümüzde $\{+(\mathrm{X}) \mathrm{n}\}$ araç durumu eki yerine ile edatı araç durumu olarak kullanılmaktadır.

Sadece ilgi eki sentaktik yapıda görev almamış, sözcük grubu olan ad tamlamasında adı ada bağlayarak aitlik bildirmiştir. 


\section{J(৫)}

\section{Kisaltmalar}

BK B = Bilge Kağan yazıtı yüzü.

BK D = Bilge Kağan yazıtı doğu yüzü.

BK $G$ = Bilge Kağan güney yazıtı yüzü.

BK G-B = Bilge Kağan yazıtı güneybatı yüzü.

BK K = Bilge Kağan yazıtı kuzey yüzü.

KT B = Köl Tégin yazıtı batı yüzü.

KT D = Köl Tégin yazıtı doğu yüzü.

KT G = Köl Tégin yazıtı güney yüzü.

KT G-B = Köl Tégin yazıtı güneybatı yüzü.

KT G-D = Köl Tégin yazıtı güneydoğu yüzü.

KT K = Köl Tégin yazıtı kuzey yüzü.

$\mathrm{T} 1 \mathrm{~B}=$ Toñukuk yazıtı 1. taş batı yüzü.

T1 D = Toñukuk yazıtı 1. taş doğu yüzü.

$\mathrm{T} 1 \mathrm{G}=$ Toñukuk yazıtı 1 . taş güney yüzü.

T1 K = Toñukuk yazıtı 1. taş kuzey yüzü.

T2 B = Toñukuk yazıtı 2. taş batı yüzü.

T2 D = Toñukuk yazıtı 2. taş doğu yüzü.

$\mathrm{T} 2 \mathrm{G}=$ Toñukuk yazıtı 2 . taş güney yüzü.

T2 K = Toñukuk yazıtı 2. taş kuzey yüzü.

\section{Kaynakça}

AKsAN, D. (2009). Her Yönüyle Dil (Ana Çizgileriyle Dil Bilim) I-II, Ankara: Türk Dil Kurumu Yayınları.

AlYıLMAZ, C. (1994). Orhun Yazıtlarının Söz Dizimi, Atatürk Üniversitesi, Sosyal Bilimler Enstitüsü, Erzurum. [Yayımlanmamış Doktora Tezi] 


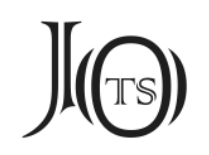

Aydın, E. (2017a). Orhon Yazıtları (Köl Tégin, Bilge Kağan, Tonyukuk, Ongi, Küli Çor), İstanbul: Bilge Kültür Sanat.

AYdin, A. (2017b). “Köktürk Abidelerinde +Da Ekinin Kullanılış Şekilleri, Cümlelerdeki Durumları ve Fonksiyon Yükleri”, Türük Uluslararası Dil Edebiyat ve Halk Bilimi Araştırmaları Dergisi, 1/9: 1-21.

BANGUOĞLU, T. (1990). Türkçenin Grameri, Ankara: Türk Dil Kurumu Yayınları.

BAŞDAŞ, C. (2009). “Orhun Abidelerinde İyelik, Belirtme ve Yükleme Hâli”, Turkish Studies, 4/8: 623-643.

DALli, H. (2018). Türkçede Söz Diziminin Yapı Birimleri, İstanbul: Papatya Yayıncrlik.

Demircan, Ö. (2005). Türkiye Türkçesinde Kök-Ek Bileşmeleri, İstanbul: Papatya Yayincilik.

EKER, S. (2010). Çağdaş Türk Dili, 6. Baskı, Ankara: Grafiker Yayıncılık.

ERASLAN, K. (2000). “Eski Türkçede Yönelme (Dativ) Hali Ekinin Yapı Fonksiyon ve İfadeleri”, İstanbul Üniversitesi Edebiyat Fakültesi Türk Dili ve Edebiyatı Dergisi, 29: 6776.

ERDEM, M. (2015). “Türk Dillerinde Belirtme-Yönelme Durum Eki Değişmesi: Bir Değerlendirme", Türkbilig, 30: 167-186.

ERGiN, M. (2009). Türk Dil Bilgisi, İstanbul: Bayrak Basım Yayım Tanıtım.

GRønBECH, K. (2011). Türkçenin Yapısı, Çev. M. AKALIN, 3. Baskı, Ankara: Türk Dil Kurumu Yayınları.

KeRimoĞLu, C. (2007). “Orhun Abidelerinde 3. Kişi İyelik Ekinden Sonra Yükleme Hâli Eki Kullanıldı mı?”, Turkish Studies, 2/3: 322-331.

KoRKMAZ, Z. (2011). Türkçede Eklerin Kullanış Şekilleri ve Ek Kalıplaşması Olayları, 5. Baskı, Ankara: Türk Dil Kurumu Yayınları.

Mert, O. (2002). Kutadgu Bilig'de Hâl Kategorisi, Atatürk Üniversitesi, Sosyal Bilimler Enstitüsü, Erzurum. [Yayımlanmamış Doktora Tezi]

ÖzDEmir, H. (2019). “Eski Türk Yazıtlarında (Tonyukuk, Köl Tegin, Bilge Kağan, Ongi, Küli Çor) İlgi Durum Eklerinin Kullanımları ve Kökenleri Üzerine”, Karadeniz Araştırmaları, 16/61: 154-165. 


\section{J(৫)}

Tekin, T. (2016). Orhon Türkçesi Grameri, Ankara: Türk Dil Kurumu Yayınları.

ÜsTÜNovA, K. (2012). Türkiye Türkçesi Ad İşletimi (Biçim Bilgisi), Bursa: Sentez Yayincilik. 